\title{
Structural control of mass movements on slopes formed of magmatic and metamorphic rocks: the case study of Wielisławka Mt. (SW Poland, Sudetes Mts.)
}

\author{
Aleksander KOWALSKI ${ }^{1,2, *}$, Damian KASZA ${ }^{3}$ and Jarosław WAJS ${ }^{3}$ \\ 1 University of Wrocław, Institute of Geological Sciences, Department of Structural Geology and Geological Mapping, \\ PI. M. Borna 9, 50-204 Wrocław, Poland \\ 2 Polish Geological Institute - National Research Institute, Lower Silesian Branch, al. Jaworowa 19, 50-122 Wrocław, \\ Poland \\ 3 Wrocław University of Science and Technology, Faculty of Geoengineering, Mining and Geology, Wyb. Wyspiańskiego \\ 27, 50-370 Wrocław, Poland
}

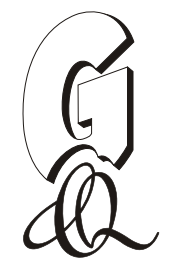

Kowalski, A., Kasza, D., Wajs, J., 2019. Structural control of mass movements on slopes formed of magmatic and metamorphic rocks: the case study of Wielisławka Mt. (SW Poland, Sudetes Mts.). Geological Quarterly, 63 (3): 460-477, doi: 10.7306/gq.1482

Associate Editor - Tomasz Bajda

We indicate the structural controls on, and provide an evolutionary model of, mass movements which developed on the slopes of a rhyolitic lava dome built of massive, sub-intrusive Permian rhyolites and its low-grade metamorphic cover, comprising Ordovician and Silurian sericite schists and metacherts (greenschist facies). The phenomena studied occur on the low-altitude, dome-like Wielisławka Mt. (370 m a.s.l.) in the Western Sudetes, SW Poland. A multidisciplinary approach involving geological and geomorphological fieldwork, LiDAR-based geomorphometric analyses, as well as analyses based on data obtained from terrestrial laser scanning (TLS), performed within old adits and shafts in the landslide area, have allowed determination of the origin and recent extent of the landslide phenomena. The geometry and development of the slip surface are closely linked with measured, existing discontinuities within the massif. As they enable observation of the initial stages of mass movement in the excavations within the cover rocks of the rhyolitic massif, the old adits and shafts are unique objects for the observation and reconstruction of landslide processes.

Key words: mass movements, brittle deformations, magmatic and metamorphic rocks, Kaczawa Metamorphic Complex, Sudetes Mts., southwestern Poland.

\section{INTRODUCTION}

Landslides and other types of mass movement (e.g., flows, falls and topples, cf. Varnes, 1978) play an important role in controlling the morphology of hillslopes and the development of geomorphological processes in mountainous geomorphic systems (Schroder, 2014). Because of the real hazards and many disasters caused by landslides (Petrakov et al., 2008; Fort et al., 2009; Avelar et al., 2011; Stoffel and Huggel, 2012; Sassa et al., 2018), the recognition and observation of these phenomena became, in the last few decades, among the most frequently discussed issues of geology, applied geomorphology and related branches of science. Many studies have been de-

\footnotetext{
* Corresponding author, e-mail: aleksander.kowalski@uwr.edu.pl Received: August 25, 2018; accepted: May 17, 2019; first published online: August 21, 2019
}

voted to the relationship between the development of landslide slopes and their internal structure and fabrics, understood as the geometrical and spatial distribution of the main structural surfaces (bedding and foliation planes, fractures, faults) in many rock types (e.g., Záruba and Mencl, 1982; Scheidegger, 1998; Margielewski, 2006; Jaboyedoff et al., 2011; Baroň et al., 2013; Humair et al., 2013; Kojima et al., 2015; Carlini et al., 2016; Schleier et al., 2016). Hence, among the most commonly undertaken geological studies are structural analyses performed in landslide-prone regions. These investigations have focused on reconstructing the mechanism of slope deformation as precisely as possible, based on observations performed within the displaced rock masses (ex situ) and analogous studies conducted in non-displaced bedrock (in situ), exposed in landslide head scarps or adjacent areas (e.g., Margielewski, 2006; Agliardi et al., 2013; Schleier et al., 2016; Margielewski and Urban, 2017). Despite advances in modern analytical methods, such as remote sensing and geographic information system (GIS) techniques (Mancini et al., 2010; Daneshvar and Bagherzadeh, 2011), detailed structural analysis as well as tra- 
ditional geological and geomorphological fieldwork still comprise fundamental and effective methods for reconstructing landslide development processes.

So far, structural analyses of landslides have been undertaken in areas where such phenomena occur in abundance, both in time and space. In Europe, such areas primarily include high- and medium-altitude mountain ranges, cliffed seacoasts and river valleys where all different genetic types of landslide have been widely observed at various scales (see summary in: Herrera et al., 2018). In Poland, the Flysch Carpathians is a mountainous area which is particularly predisposed to landslide development. Over 60,000 individual landslides have been recorded and described there, in particular by the Polish Geological Survey, since the end of the 1960s (Poprawa and Rączkowski, 2003; Wójcik and Wojciechowski, 2016). In comparison to the Polish Flysch Carpathians, the Sudetes - a medium-high mountain range located in SW Poland - has so far been considered as an area devoid of landslide hazards (Jahn, 1960). This is reflected in many summary reports on mass movements in Poland and Europe (Herrera et al., 2018), in which Lower Silesia has been depicted as an area where landslide phenomena occur rather infrequently. This opinion has changed in the last decade or so, mainly due to the identification and description of several hundreds of hitherto unrecognized landslide forms in the Sudetes (Synowiec, 2003; Migoń et al., 2014, 2016a, b; Ró ycka et al., 2015; Duszyński et al., 2017; Jancewicz and Traczyk, 2017; Kowalski 2017a, b; Kowalski and Wojewoda, 2017; Kowalski and Makoś, 2019; Sikora and Wojciechowski, 2019).

This paper explains the formation and mechanisms of landslide phenomena occurring on the northern slopes of the dome-shaped, rhyolitic Wielisławka Mt. (373 m a.s.I.) located in the Kaczawa Foothills of the Western Sudetes. Geological and geomorphological field studies made in the last few years clearly show transformation of this hill by slope-scale gravitational processes (see Kowalski and Wojewoda, 2017). Three spatially and genetically interconnected landslide areas have been recognized on the northern slopes of Wielisławka Mt.: they are characterized by different morphologies and origins of gravitational displacement and cover areas of 8.06, 6.67 and 6.73 ha, respectively. This report is focused on the largest, western, landslide, on which intense mining activity took place between the 14th and 18th centuries (Maciejak et al., 2017). In the remains of underground excavations, located directly below the landslide, occur a series of deformation structures indicating dilatation (Reynolds, 1885; Neuendorf et al., 2005) which in consequence may lead to the development of a subsequent low-angle slip surface, and then the formation of a deep-seated landslide (cf. Margielewski and Urban, 2017). The western landslide was selected for our investigations due to perfect bedrock exposure within the landslide head scarp and accessible mining excavations, which has allowed determination of the influence of the bedrock structure on the development of landslide forms.

\section{GEOMORPHOLOGICAL AND GEOLOGICAL SETTING}

Wielisławka Mt. is located in southwestern Poland, in the Western Sudetes, Kaczawa River valley, between Ró ana and Nowy Kościół in the north and Sędziszowa in the south (Fig. 1). According to the physical-geographical subdivision of Poland (Kondracki, 2002), the area represents the central part of the Kaczawa Foothills. The area is characterized by a variable, hilly landscape with elevations ranging from $224 \mathrm{~m}$ a.s.I. (bottom of the Kaczawa River valley near Nowy Kościół village) to 474 m a.s.I. (Bucze Wielkie Mt.). Characteristic morphological features of this region comprise isolated, conical hills (Czeska Góra, Wołek, Wygorzel Zawodnia hills) and large dome-like massifs (Bucze and Wielisławka) rising above low-relief denudation plains located at elevations in the range of 270 and $330 \mathrm{~m}$ a.s.I (Fig. 1A).

Denudation plains are deeply dissected by V-shaped stream valleys with rocky slopes and depths of $\sim 35 \mathrm{~m}$ (e.g., valley of the Piekiełko Stream to the south of Nowy Kosciół; cf. Fig. 1A). NW-SE oriented ridges with poorly marked peaks (Dłu yca, Krowia hills) are also present in the study area. The upper slopes of these ridges fall within the range of $40-50^{\circ}$; walls, rock ribs and cliffs are often present in their upper segments, and accumulations of rocky blocks and debris occur beneath the slopes. The most significant element of the morphology of the area is the Kaczawa River valley, which along its gorge ranges from about $150 \mathrm{~m}$ to over $300 \mathrm{~m}$ in width. The river valley is located at elevations from about $245 \mathrm{~m}$ a.s.l. near Sędziszowa to about 224 m a.s.l. near Nowy Kościół.

Many landslides affecting the slopes of the Kaczawa River valley have been documented (Kowalski and Wojewoda, 2017; see Fig. 1). The widest, western landslide (8.06 ha) occurs on the densely forested, northern slopes of the three-peaked Wielisławka massif (from the west: at 376.3; 365.6 and $372.2 \mathrm{~m}$ a.s.I.) and is one of the elements of a landslide complex covering an area of 21.5 ha.

The morphology of the part of the Kaczawa River valley described closely reflects the geological structure of the bedrock (Fig. 1B) and largely depends on the resistance of rocks to weathering and erosion (cf. Traczyk, 2011). Geologically, the Kaczawa River gorge was formed within metamorphic rocks assigned to the Kaczawa Metamorphic Complex (KMC; southern part of the study area) and within sedimentary and volcanic rocks that build the central and northern parts of the North Sudetic Synclinorium (NSS; Teisseyre et al., 1957; cf. Fig. 1B). Both of these geological units are located in the northern part of the Sudetic Block - an elevated element of the northeastern termination of the Bohemian Massif. In the traditional regional scheme proposed by Teisseyre et al. (1957), the KMC and NSS were treated jointly as the Kaczawa Unit. This unit included rocks of the KMC assigned to the lower (metamorphic) structural stage (Lower Kaczawa stage), whereas the non-metamorphosed sedimentary and volcanic rocks of the NSS have been assigned to the upper structural stage. These units are separated by a regional unconformity.

Metamorphic rocks occurring on the northern slopes of Wielisławka Mt. are largely metasedimentary rocks exposed in the western part of the Rzeszówek-Jakuszowa Unit, one of the units of the KMC, within a subordinate tectonic unit known as the Świerzawa Horst (ŚH; cf. Fig. 1B). The KMC is a unit with an extremely complex geological structure, built of metasedimentary and metavolcanic rocks, strongly folded, faulted and weakly metamorphosed (lower/middle greenschist facies) during the Variscan orogeny (cf. Urbanek et al., 1975; Baranowski et al., 1990; Kryza and Muszyński, 1992; Cymerman, 2002). The rocks assigned to the KMC include mainly phyllites, sericite schists, metasandstones, metamudstones and crystalline marbles, as well as rocks that originated due to submarine volcanism and plutonism: metabasalts (pillow-lavas) and basaltic tuffites, metarhyolites, metarhyodacides, metadolerites and metagabbros; they represent the Paleozoic (Cambrian to Lower Carboniferous/Mississippian; cf. Baranowski et al., 1990).

Sericite, siliceous and graphite schists, metacherts and siliceous metasiltstones, and subordinate metasandstones, repre- 


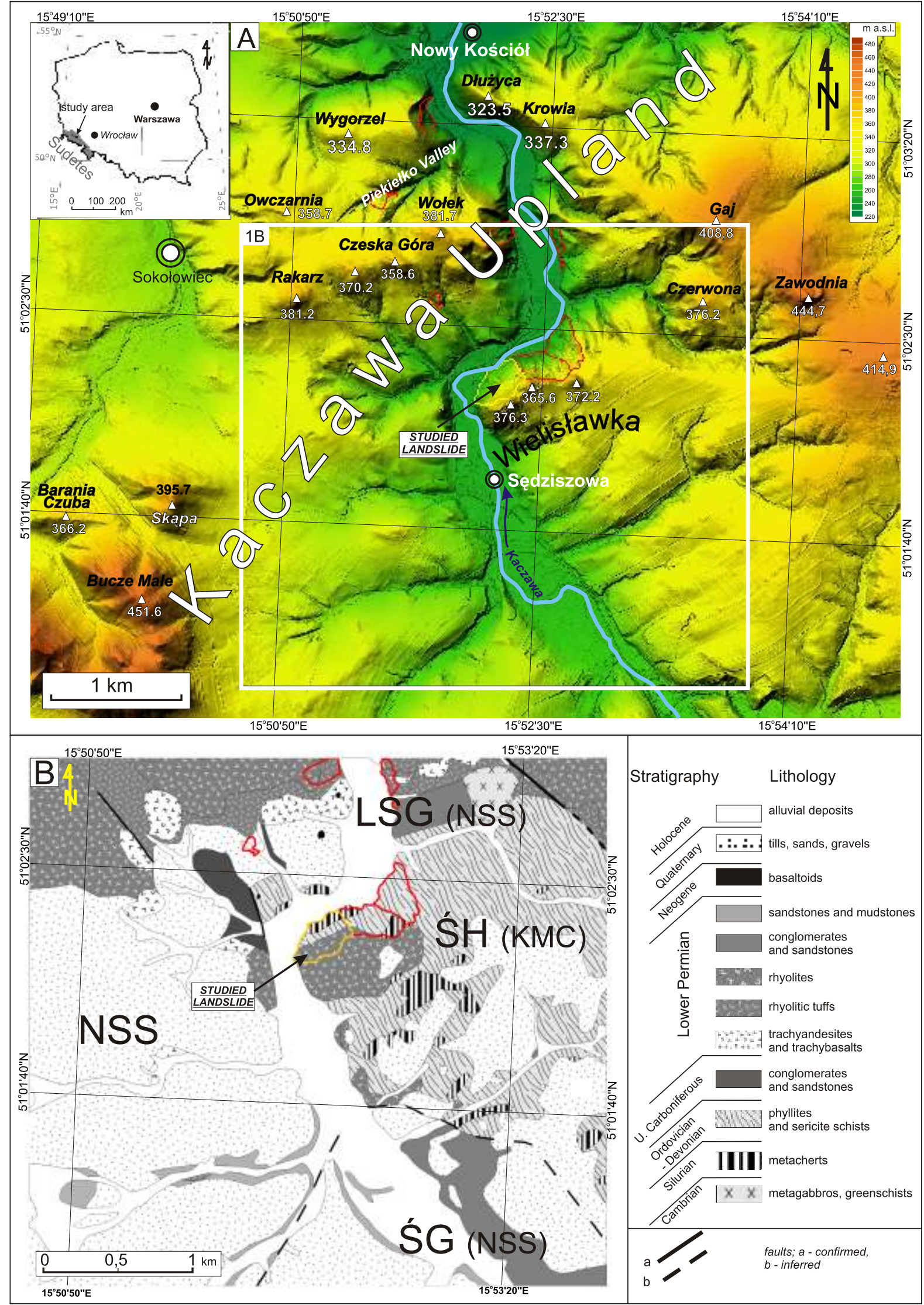

Fig. 1. Location map of the study area

A - lidar-based shaded relief map with superimposed landslides (red polygons) in the Kaczawa River valley; the western landslide described in this paper is marked in yellow; $\mathbf{B}$ - geological sketch map of the study area (based on Zimmermann and Kühn, 1929; Frąckiewicz, 1958; Milewicz and Kozdrój, 1995 and the lead author's own studies); KMC - Kaczawa Metamorphic Complex, NSS - North Sudetic Synclinorium, LSG - Leszczyna Semi-Graben, ŚH - Świerzawa Horst, ŚG - Świerzawa Graben 
senting the Ordovician-Devonian, occur on the slopes of Wielisławka Mt. (Fig. 1B; Milewicz and Kozdrój, 1995). These rocks are considered as hemipelagic silt- and clay-rich sediments (Baranowski, 1975) that originated from the deposition of turbidity currents (flysch). Metasedimentary rocks occur in the study area in a normal position. Foliation which developed in these rocks during metamorphism (foliation $\mathrm{S}_{1}$ sensu Cymerman, 2002) is usually oriented in accordance with the primary bedding surfaces of the sedimentary rocks $\left(\mathrm{S}_{0}\right)$ (protolith).

In the study area, metamorphic rocks of the KMC are unconformably covered by rocks of the NSS (upper Kaczawa stage; cf. Fig. 1B; Baranowski et al., 1990) or occur in tectonic contact with this unit. The NSS is composed of weakly deformed Upper Carboniferous (Pennsylvanian), Permian and Triassic sedimentary and volcanic rocks, which together with the Upper Cretaceous deposits compose the upper Kaczawa stage (Teisseyre, 1957). These rocks, both continental and marine, as well as products of Permian volcanism, infilled the North Sudetic Basin (NSB) at various stages of its development (Śliwiński et al., 2003). The NSB started to develop as a intramontane trough (tectonic graben), which formed near the present-day town of Świerzawa during the Late Carboniferous (Pennsylvanian) (Wojewoda and Mastalerz, 1989; Solecki, 1994) due to large-scale regional extension of the KMC basement. In the Early Permian, this depression gradually expanded and became filled with coarse sediments of alluvial fans formed in the foreland of mountain ranges, as well as sediments of gravel-bed rivers. In the Early Permian, the process of basin infilling was interrupted by intense volcanic activity (Kozłowski and Parachoniak, 1967). This produced alkaline and acidic, extrusive and subvolcanic magmatic bodies, which are mostly represented by trachyandesites, trachybasalts and rhyolitoids such as the Wielisławka intrusion (Awdankiewicz and Szczepara, 2009; Mikulski and Williams, 2014). They are commonly associated with volcanic tuffs. In the Early Permian, rhyolites of the present-day Wielisławka Hill intruded the metamorphic rocks of the Rzeszówek-Jakuszowa Unit, which from the west are unconformably covered by or occur in a tectonic contact with Upper Carboniferous (Pennsylvanian) and Lower Permian sedimentary rocks of the NSS. These deposits are overlain from the north by Upper Permian (Zechstein), Lower Triassic (Buntsandstein) and Upper Cretaceous strata of the NSS. Many zones of hydrothermal mineralisation are observed in the marginal zones of the Wielisławka rhyolite intrusion; ore-bearing minerals such as pyrite, galena, sphalerite, arsenopyrite and chalcopyrite are common (Mikulski, 2007). Mining of these mineral ores was carried out on the slopes of the hill from the late 14th till the 18th century (Maciejak et al., 2017).

\section{MATERIALS AND METHODS}

Studies of the Wielisławka massif comprised spatial data analysis and fieldwork. The main part of this study was based on mapping, with preliminary recognition of the landslide relief investigated requiring morphometric analysis using GIS software with application of LiDAR-derived digital elevation models (DEMs) with a resolution of $1 \times 1 \mathrm{~m}$. Then, detailed field mapping was carried out, with geological and geomorphological observations. Field studies were focused on the identification of structural controls and their impact on landslide development and also precise spatial determination of the lithological boundaries. The last stage of fieldwork, aimed at determining the precise location and range of the landslide-affected slopes in 3D, included a geodetic survey of the accessible underground excavations using terrestrial laser scanning.

\section{GEOMORPHOLOGICAL ANALYSIS AND FIELDWORK}

Detailed geomorphometric analyses based on LiDAR DEMs with a resolution of $1 \times 1 \mathrm{~m}$ were performed for assessment of the range of landslide phenomena that had been reported earlier on the northern slopes of Wielisławka Mt. (see Kowalski and Wojewoda, 2017). Elevation data were acquired from airborne laser scanning (ALS), conducted in Poland in 2011-2014 as a part of the IT System of the Country's Protection against Extreme Hazards (ISOK). Results of laser scanning were made accessible by the Polish Centre of Geodetic and Cartographic Documentation (CODGiK) as XYZ point data with a density of $\sim 4-6$ point $/ \mathrm{m}^{2}$ and average elevation error not exceeding $0.3 \mathrm{~m}$ (Report, 2011). Point data sets were used to construct digital elevation models. Based on LiDAR DEMs, the basic morphometric parameters of the landslide forms recognized in the field were calculated. Additionally, shaded relief maps with various levels of exaggeration, lighting angle and direction, slope and exposure maps have been prepared to visualise the variability of these forms. A standard procedure was generation of morphological cross-sections perpendicular to the elongation of the landslide colluvial zones. Shaded relief maps were also used as topographic maps for geomorphological sketches and geological maps made in the field using ArcPad software (.shp format). MicroDEM, Move (Midland Valley) 2017.2, SAGA GIS v. 3.0.0, Global Mapper v. 15.0, and Surfer (Golden Software) v. 9.0 software were used at this stage of the research. All material was processed in the Polish PUWG 1992 projection.

Fieldwork took place in 2016-2018 during a geological survey in the northern part of the Świerzawa Graben. Morphological features were located in the field with the application of a Nomad Trimble and Nomad Juno ST GPS with 1 to $3 \mathrm{~m}$ accuracy and a Pentagram PathFinder Logger P3106 with precision of position determination $<3 \mathrm{~m}$. Measurements of the elements of landslide morphology were performed using a Bushnell laser rangefinder. Particular care was taken to distinguish between anthropogenic forms caused by mining activity from the landslide morphology (see Kowalski and Wojewoda, 2017). The terminology applied for the description of landslides accords with the commonly used classifications of mass movements (Varnes, 1978; WP/WLI, 1990, 1993; Dikau et al., 1996; Hungr et al., 2014).

\section{GEOLOGICAL FIELDWORK AND MEASUREMENT OF STRUCTURAL DISCONTINUITIES}

Detailed geological mapping in the Wielisławka area conducted by the authors was focused on determining the influence of the bedrock structure on landslide development, as well as the precise extent of lithological units. This allowed assessment of the accuracy of current published geological maps. During fieldwork, much attention was paid to the precise location and determination of geological boundaries, especially in low-grade metamorphic (tectonic or primary sedimentary contacts) and igneous rocks.

Recognition of the mechanism of gravitational processes on slopes affected by mass movements requires detailed structural analyses (e.g., Záruba and Mencl, 1982; Margielewski, 2006; Jaboyedoff et al., 2011; Baroň et al., 2013; Humair et al., 2013; Kojima et al., 2015; Carlini et al., 2016; Schleier et al., 2016) in exposures of igneous and metamorphic rocks. These analyses here include measurements of the main structural discontinuities and other features (fractures, folds, axes of contraction columns in the rhyolites, foliation planes, cleavage), both within the landslides (ex situ exposures) and in the bedrock (in 
situ) exposed on the surface and within old adits. In low-grade metamorphic rocks, the penetrative planes of metamorphic foliation $\mathrm{s}_{1}$ (see Cymerman, 2002) have been measured. In metamorphic rocks, mainly metacherts, two main joint sets $j_{1}$ and $j_{2}$ were determined, as well as two co-occurring sets of oblique joints $j_{3}$ and $j_{4}$. In volcanic rocks a total of 5 main fracture sets $\left(j_{1}\right.$, $\mathrm{j}_{2}, \mathrm{j}_{3}, \mathrm{j}_{4}$ and $\mathrm{j}_{5}$ ) were distinguished. Structural mapping involved also description of joint surfaces and identification of fault planes. Numerous mesostructural kinematic indicators as well as fracture surface markings (FSM; cf. Petit, 1987; Bahat, 1991), such as striated ridges, grooves, slickensides, low-angle shears, hackle fringes and en echelon cracks, were described and measured. Measurements of the position of structural features were supplemented with measurements made with the mobile application FieldMove Clino (Midland Valley). Measurements of structural elements are shown on great circle diagrams and on pole point diagrams and contour diagrams with equal-area projection on the lower hemisphere of the equalarea Schmidt-Lambert network. Additionally, axes of contractional columns in rhyolites were plotted on rose diagrams with a class interval of $10^{\circ}$.

\section{TLS MEASUREMENTS}

Precise inventory of the underground excavations on Wielisławka Mt. was made with the use of terrestrial laser scanning (TLS). Due to the specific character of the objects analysed partly collapsed adit entrances, narrow pathways and the presence of collapses, a manual ZEB Revo scanner using SLAM technology (Simultaneous Localization And Mapping; Berns and von Puttkamer, 2009; Romagós et al., 2010; Werner, 2014; Birk and Pfingsthorn, 2016; Kong and Lu, 2017; Nocerino et al., 2017) was applied. ZEB Revo is a small, manual, latest generation scanner, successfully applied in surveys of closed objects (effective measurement range with a laser beam is about $30 \mathrm{~m}$ ). The scanner combines two main systems: a scanning head with a velocity of about 42000 point/min and an Inertial Measurement Unit (IMU) used for determining the relative position of the scanner during the measurement. A commonly indicated asset of the system is its ability to work without a GNSS signal (Dewez et al., 2016; Eyre et al., 2016; Sammartano and Spanb, 2018; Tucci et al., 2018; Wajs et al., 2018).

The effect of scanning performed during surveys along the excavations was a set of xyz spatial data, connected in a uniform point cloud using the SLAM algorithm. The dataset obtained was used to construct a 3D digital elevation model of the underground excavations. Reference of the datasets obtained was made using 3 reference points localised beneath the slopes of Wielisławka Mt. using the RTK GNSS technique.

\section{RESULTS}

\section{LANDSLIDE DESCRIPTION}

The western landslide is developed on the NNW slopes of the highest peak of the Wielisławka massif (376.3 m a.s.I.), which is the culmination of an elongated, WSW-ENE ridge bounding the gorge of the Kaczawa River to the south (Fig. 2). Mass movements took place within Lower Permian rhyolites, which form the northern contact with Silurian metacherts, siliceous and sericite schists.
In the upper part of the landslide there are steep, arch-shaped, distinctive head scarps which are nearly $25 \mathrm{~m}$ high and $\sim 400 \mathrm{~m}$ wide. Those located at 250-340 m a.s.l. were formed in heavily jointed rhyolites and have an inclination exceeding $50^{\circ}$. The WSW-ENE orientation of the scarps is consistent with the extension of the morphological ridge of Wielisławka Mt. Above the head scarps, particularly in the western part of the massif, isolated rocky forms attaining heights up to $7 \mathrm{~m}$ occur in an in situ position. Below the head scarps there is a landslide body with a diverse surface morphology. Colluvial benches are visible within them; they are separated by flat parts of the slope which in places form colluvial swells. The landslide bedrock within the head scarp is exposed along 150 m and consists of densely fractured, massive rhyolites. The foot of the scarp is covered by blocky talus. In the central part of the landslide the head scarps are poorly visible and attain here a height of up to $5 \mathrm{~m}$ and a width of $\sim 120 \mathrm{~m}$, without bedrock exposures. In the mid-slope section, below the head scarps there are colluvial bulges and blocky covers composed of angular blocks of rhyolite which here form narrow blocky toes and creeps. The north-easternmost part of the landslide is not easily visible and it is most intensely modified by mining activities - entrances to over a dozen short adits (presently infilled) and small slagheaps are observed. The adits were dug at the contact between the rhyolites and the metamorphic rocks.

In addition, 60 to 100 m-wide distinctly marked landslide scarps occur in the middle section of the landslide slope. The most prominent scarp, with small exposures of sericite schist and phyllite, is arch-shaped, has a width of $\sim 100 \mathrm{~m}$ and a height of $12 \mathrm{~m}$ (Fig. 2). Below the scarp occurs a slid block, which is bounded from the outside by an insignificant (up to $\sim 1.5 \mathrm{~m}$ ) landslide ridge with an indistinct secondary scarp. Within the landslide bulge developed below the scarp there occur small, water-filled hollows and anthropogenic sinkholes. These last forms probably represent the oldest stage of mining activities in the area (see Maciejak et al., 2017), dated to the 14th century. Slopes of the colluvial bulge are cut in their lower parts by a forest road with exposures of grey sericite schist. The landslide toe is poorly preserved and has probably been partly levelled during the mining. A fragment of the landslide tongue is preserved in the middle part of the landslide, where the Młynówka Stream meets the Kaczawa River (Fig. 2). In the lowermost part of the landslide, the slope is undercut by the Kaczawa River valley, the slopes of which are rocky in character and inclined at up to $60^{\circ}$. Rocky walls and individual cliffs occur on the valley slopes in the lower part of the western landslide; they reach up to $4.5 \mathrm{~m}$ in height and are composed of metacherts and siliceous schists.

\section{OLD ADITS}

Two unobstructed networks of underground excavations occur in the area of the landslide investigated: object no. 1 (Fig. 2 and $3 \mathrm{~A}$ ) with a total length of $\sim 283 \mathrm{~m}$ and object no. 2 with a length of $\sim 33 \mathrm{~m}$ (Fig. 3B). Object no. 1 is known in the literature and in tourist guides as the "Wielisławska Cave" (e.g., Cedro et al., 2009). These excavations were described firstly by Zöller (1936) and are situated on the prolongation of the head scarp (middle part of slope) and were probably dug along an earlier landslide fracture (Kowalski and Wojewoda, 2017).

Object no. 1 is located at $248 \mathrm{~m}$ a.s.l., $25 \mathrm{~m}$ to the SE from where the Młynówka Stream joins the Kaczawa River, 8 m above the valley bottom (cf. Fig. 2). The initial adit (section A; cf. Fig. 3A), $39 \mathrm{~m}$ long and NW-SE-oriented, terminates with a collapse and cross-cut. In the next section (section B), the adit 


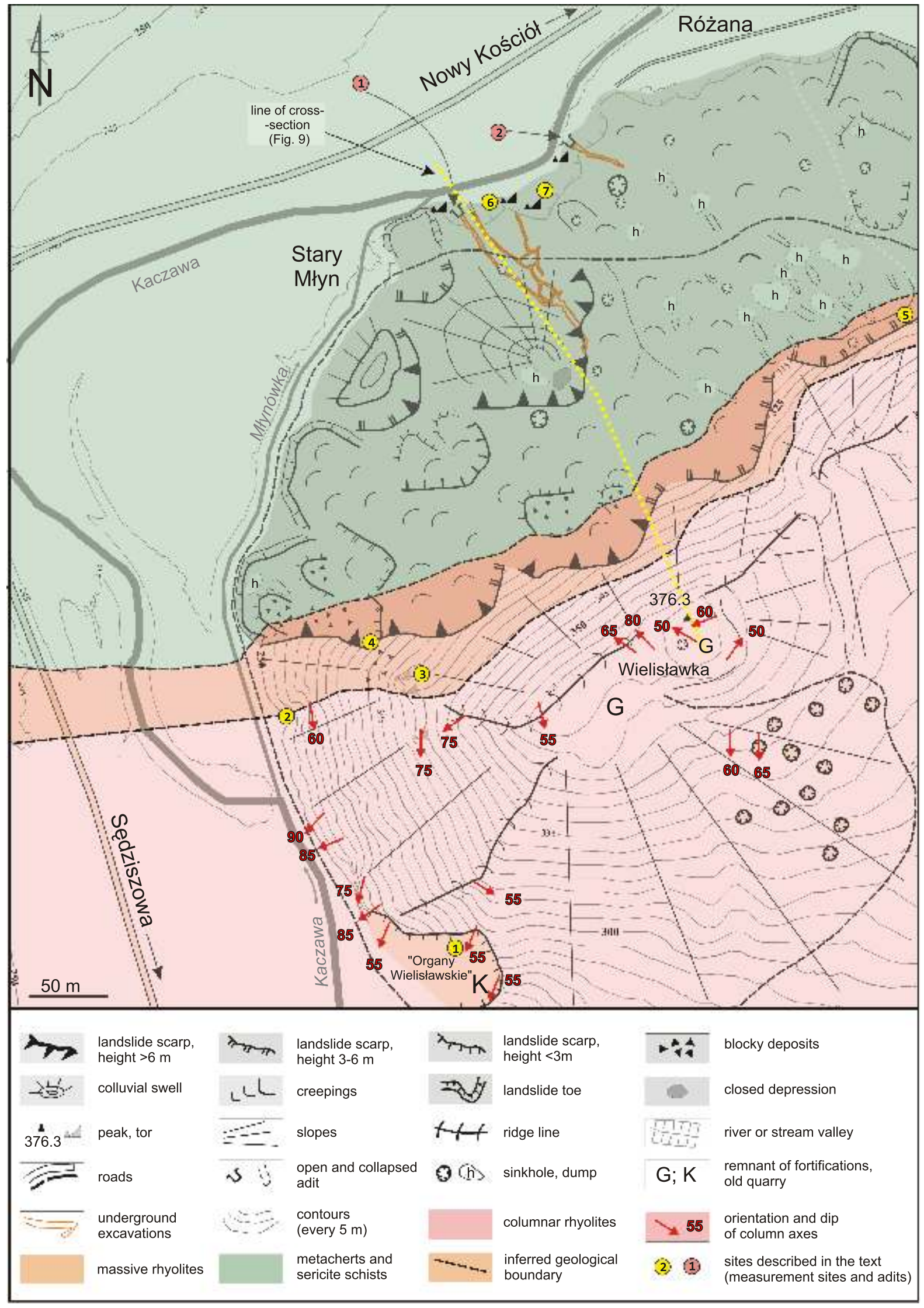

Fig. 2. Geomorphological map of the western landslide with main geological features superimposed

Geology modified after: Zimmermann and Kühn (1929), Frąckiewicz (1958), Milewicz and Kozdrój (1995); exposures described in the text are marked in circles; yellow, dashed line of cross-section (Fig. 9) is marked 


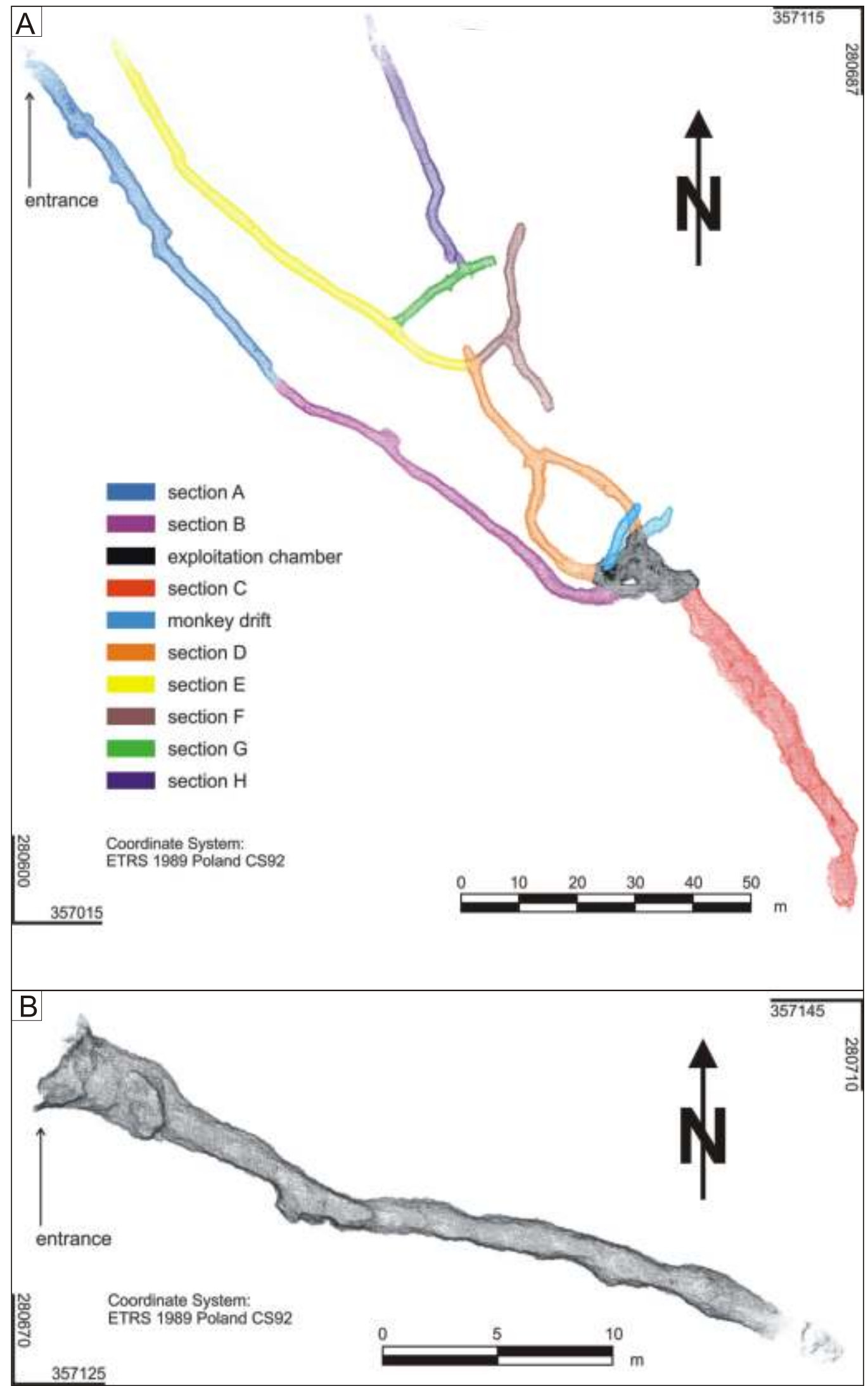

Fig. 3. 3D models of underground excavations in the Wielisławka massif derived from TLS 
continues to the SE for another $40 \mathrm{~m}$, leading to a $5 \times 5 \mathrm{~m}$ exploitation chamber. Five pathways branch from the chamber in different directions. The shortest, monkey drifts, 5 and $8 \mathrm{~m}$ long, respectively, have been excavated towards the ENE. Towards the SE leads a pathway that is $63 \mathrm{~m}$ long (section $\mathrm{C}$ ). The pathway terminates with a collapse located below the landslide head scarp in the middle part of the slope (SE part of section C), $\sim 39 \mathrm{~m}$ below the land surface. Excavations of two $15 \mathrm{~m}$ long pathways (section D) branch from the exploitation chamber towards the NW. The pathways pass into the subsequent adit (section E) with a length of $\sim 50 \mathrm{~m}$. Short monkey drifts ending in faces branch from pathway $D$; pathway $F$ is $18 \mathrm{~m}$ long and pathway $\mathrm{G}$ is $11 \mathrm{~m}$ long. An adit (section $\mathrm{H}$ ) leads also to the pathway (section $\mathrm{G}$ ) but its entrance is collapsed.

The entrance to object B is located at $249 \mathrm{~m}$ a.s.I., on the slope of the Kaczawa Valley, $\sim 40 \mathrm{~m}$ to the SW from the bridge in Ró ana village (cf. Fig. 2). The oval adit entrance is $\sim 3 \times 2.5$ $\mathrm{m}$ in size. The $\sim 35 \mathrm{~m}$ long excavation is oriented towards the SE (Fig. 3B). The adit has a width reaching $2 \mathrm{~m}$, is up to $1.8 \mathrm{~m}$ high and ends in a collapse.

\section{MEASUREMENTS OF STRUCTURAL ELEMENTS}

\section{RHYOLITIC CLIFFS AND LANDSLIDE HEAD SCARPS}

Measurements of structural discontinuities were made in sites located in situ, including old quarries and cliffs located in the northern and western slopes of Wielisławka Mt. (localities nos. 1, 2, 3 on Fig. 2) and exposures within the head scarps of the main landslides (localities nos. 4 and 5). In the southern and southwestern part of the hill, densely fractured rhyolites with distinct columnar joints occur in natural and artificial exposures (cf. Fig. 2 and 4A, B). Rhyolitic columns in the southern part of the massif are long narrow structures displaying regular 4- and 5-sided shapes. 3- and 6-sided columns as well as irregular forms occur infrequently (Jerzmański, 1956). The exposure with the best developed rhyolitic columns is located in an abandoned quarry known as the "Organy Wielisławskie" ("Wielisławskie Organs"; loc. no. 1; Fig. 4A), which is protected as a natural monument. Column axes are inclined here at variable angles from 55 to $85^{\circ}$ to the SW. The quarry shows columns arranged in a fan shape (Fig. 4A). Fracture planes related to magmatic foliation, inclined at up to $45^{\circ}$ to the NE, occur normal to the column axes (Awdankiewicz and Szczepara, 2009).

To the north, the orientation and dip of the columns change significantly - on the Wielisławka ridge the dips are to the NE and NW, and in some cases they attain an opposite orientation (Fig. 4B, C). Farther to the north the columnar rhyolites pass into irregularly fractured massive varieties with a dense network of discontinuities. Based on measurements of the fracture planes in a quarry (loc. 2) located $\sim 50 \mathrm{~m}$ from the margin of the landslide head scarp, three steep joint sets with dips at 70 to $90^{\circ}: j_{1}$ (NNW-SSE-oriented), $j_{2}$ (ENE-WSW-oriented) and $j_{3}$ (N-S-oriented), and two sets with dips at 35 to $55^{\circ}$ (NE-SW-oriented), with the dominating dip to the SE $\left(\mathrm{j}_{4}\right)$ and to the NW ( $\left.\mathrm{j}_{5}\right)$ have been distinguished (Fig. 4D). Joint set $j_{5}$ observed in massive rhyolites corresponds to the orientation of fluidal textures in the columnar rhyolites. Five joint sets with a similar orientation have also been distinguished within the cliffs (loc. 3) exposed in the western elongation of the Wielisławka ridge, on the eastern slope of the Kaczawa Valley (Fig. 4E). In turn, in exposures in the main scarp of the landslides (loc. 4 and 5; Fig. 4F, G), sets $j_{1}, j_{2}$ and $j_{3}$ attain a much wider scatter of strike orientations in comparison to those at localities 1,2 and 3. Slickensides were not observed on fracture planes in exposures located above the landslide area and within the main head scarps. In turn, localities nos. 4 and 5 commonly contain fractures developed along joint sets $j_{1}, j_{2}$ and $j_{5}$. Their separation sometimes reaches 15 $\mathrm{cm}$, particularly at locality no. 3 .

\section{MEASUREMENTS OF STRUCTURAL ELEMENTS WITHIN OLD ADITS}

Structural measurements were made in all accessible excavations of objects nos. 1 and 2 (Fig. 5). Both objects were excavated entirely within the KMC rocks - metacherts, phyllites, siliceous schists and subordinate sericite schists. In sections A, B and $E$ of object no. 1, foliation planes are inclined mainly towards the NW, subordinately to the NE and SW at low angles (5 to $35^{\circ}$; Fig. $5 \mathrm{~A}$ and $6 \mathrm{~A}$ ). In some cases over longer distances in adits, particularly in the terminal parts of section $E$ and in the middle part of section $\mathrm{A}$, foliation planes are homoclinally $\mathrm{N}$ and NW dipping. Local variability of orientations and dips of the foliation planes $s_{1}$ are related to the presence of wide-radius, non-cylindrical folds with axes inclined at variable angles to the NE-SW, subordinately to the NW-SE (Fig. 6B). Small-scale folds were observed infrequently, especially in the distal parts of section C (Fig. 6C). Discontinuity planes within homoclinally dipping metamorphic rocks (measurements in section $A$ ) may be grouped into two main joint sets $\left(\mathrm{j}_{1}\right.$ and $\mathrm{j}_{2}$ ) of steeply dipping fractures $\left(65-85^{\circ}\right)$ with orientations at NNE-SSW $\left(j_{1}\right)$ and WNW-ESE ( $\mathrm{j}_{2} ;$ Fig. 6D), as well as sets of oblique joints with orientations at NW-SE $\left(\mathrm{j}_{3}\right)$ and WSW-ENE $\left(\mathrm{j}_{4}\right)$ and dips at $75-90^{\circ}$. Local variability of dip, strike and density of fractures result from their position with regard to the axes of the wide-radius fold structures. Within the fold hinges, the fractures are usually very dense (axial cleavage). These structures occur only locally. In the eastern part of the adit, in sections $\mathrm{C}, \mathrm{H}$ and in the monkey drifts, foliation planes become steeper, to about $70^{\circ}$, and dip to the NW and SW (cf. Fig. 5A).

This steepening is related to the presence of numerous, SW to NE dipping normal dip-slip faults with dips ranging from 45 to $90^{\circ}$ (Fig. 6E, F). Surfaces of these faults are commonly polished or striated and display the presence of slickensides, asymmetrical fault steps and short R-shear fractures (Fig. 6G), which may be observed particularly in section C. Cataclasites and fault breccia occur also in the fault zones; they comprise chaotically arranged blocks and clasts of sericite schist and metachert (Fig. $6 \mathrm{H}$ ) with dimensions exceeding $3 \mathrm{~m}$ in some instances. Very often the sericite schists display intense cataclasis, blurring of the primary structure and plastic deformation related to the presence of secondary clay minerals. The southern part of the excavations (section $\mathrm{C}$ ) is characterized by numerous collapses and tightenings caused by the presence of faults. The course of pathway $\mathrm{C}$ and the strike of the observed faults correspond to those from the eastern part of the landslide head scarp located in the middle part of the slope.

Numerous extensional cracks and fractures with spacings up to $20 \mathrm{~cm}$ have also been observed within excavations of object no. 1 (Fig. 7). In the first part of the adit (section A), the cracks dip at low angles to the NW (up to $35^{\circ}$ ) and have an E-W or NW-SE strike (Fig. 7A). High-angle R' fractures reach the low-angle fractures. The geometry of the fractures recognized is consistent with low-angle dilatation cracks (cf. Margielewski and Urban, 2017). In turn, in the middle part of the adit (section $\mathrm{B})$ dominate NE-SW-oriented high-angle cracks and fractures dipping to the NW and SE. In some cases the cracks are filled with crushed rock material, and the rock blocks that bound them display evidence of displacements (Fig. 7B). Fissure orientations correspond to the recognized joint sets $j_{1}$ and $j_{2}$, sub- 


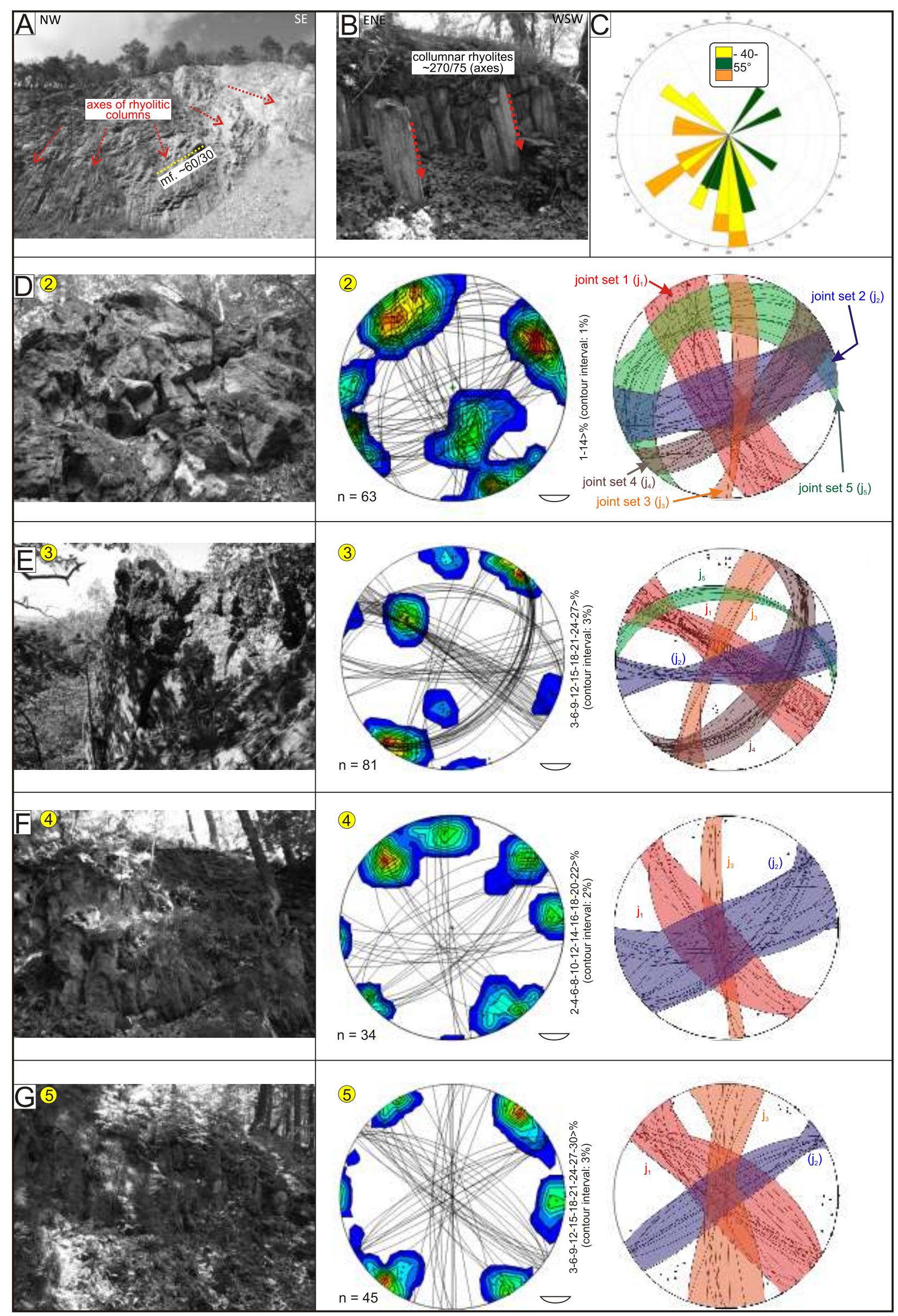




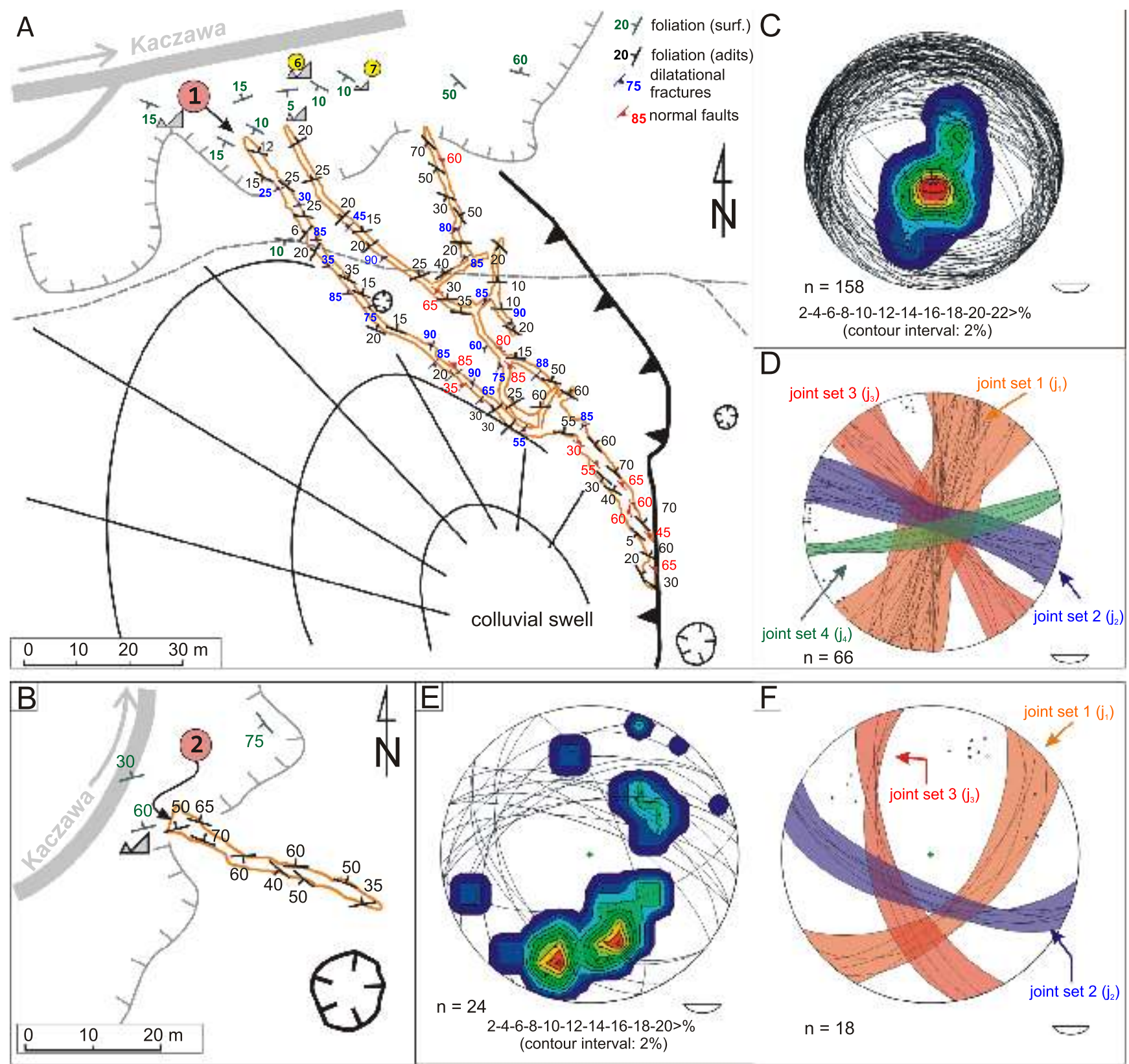

Fig. 5. Results of structural measurements made in accessible excavations of objects nos. 1 and 2

A - map of object no. 1 with marked measurements of foliation, dilatational fractures and fault planes; $\mathbf{B}$ - map of object no. 2 with marked measurements of foliation planes; for other symbols see Figure 2 (morphology of the landslide area); $\mathbf{C}$ - foliation planes measured within object no. 1 shown on contour, pole point and great circle diagrams; D - interpretation of joint sets distinguished within object no. 1 (measurements in section A) shown on pole point and great circle diagrams; $\mathbf{E}$ - foliation planes measured within object no. 2 shown on contour, pole point and great circle diagram; $\mathbf{F}$-interpretation of joint sets distinguished within object no. 2 shown on pole point and great circle diagrams

Fig. 4. Rhyolites exposed in situ in localities in the vicinity or within the western landslide

A - columnar rhyolites exposed in an abandoned quarry ("Organy Wielisławskie"); axes of rhyolitic columns and planes of magmatic foliation (mf.) are marked; B - columnar rhyolites exposed at the top of Wielisławka Mt.; C - orientation of column axes within rhyolites shown on rose diagram with a class interval of $10^{\circ}$; colour scale corresponds to $15^{\circ}$ classes of dip angles; D - irregularly fractured rhyolites exposed in an abandoned quarry located $\sim 50 \mathrm{~m}$ from the margin of the landslide head scarp; $\mathbf{E}$ - densely fractured rhyolites exposed within a cliff above the landslide head scarp; F, G - exposures of densely fractured rhyolites within the head scarp of the landslide; main discontinuities (joint surfaces) are shown for each site on contour and great circle diagrams to right; interpretation of joint sets distinguished is shown on pole point and great circle diagrams; numbers of localities are marked (see Fig. 2) for each site 

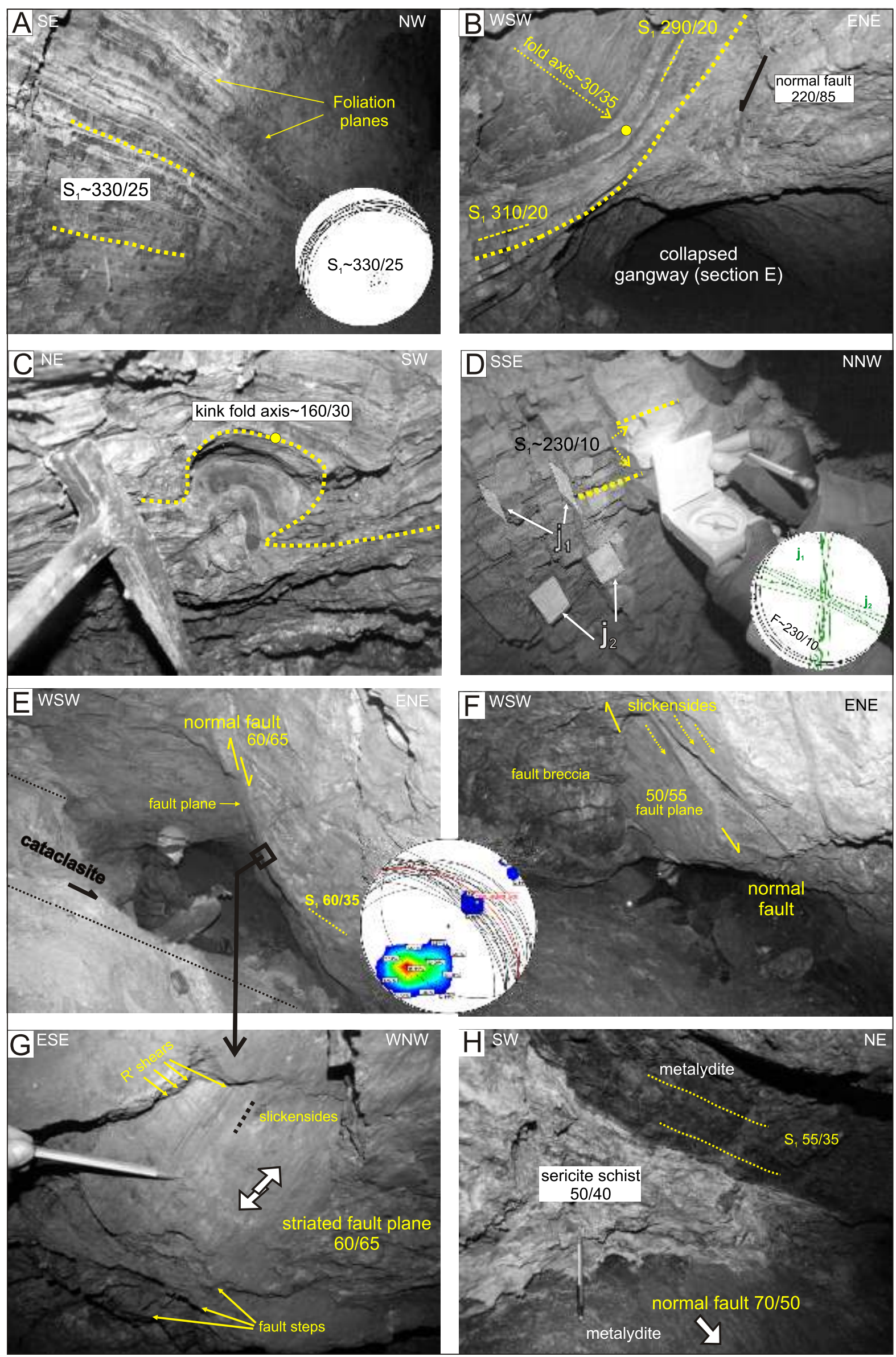
ordinately $\mathrm{j}_{4}$ (cf. Fig. 5A). High-angle fissures occur especially in sections $B, D, G$ and $H$, predominantly within sections $C, E$ and $\mathrm{F}$ and on the top of the exploitation chamber (cf. Fig. 7C, D, E). There are subordinate cracks concordant with the adit's orientation (NW-SE).

Excavations of object no. 2 have been dug in metacherts, graphite schists and subordinately in sericite schists (KMC). Foliation planes in the first part of the adit dip steeply (up to $70^{\circ}$ ) to the NE (Fig. 5D), whereas in the farther parts of the adit the foliation planes show a chaotic distribution and are folded (Fig. $5 E)$. There commonly occur isoclinal folds with WNW-ESE or $\mathrm{E}-\mathrm{W}$-oriented axes. Extensional fractures have not been observed in the adit, whereas cataclastic and breccia zones built of chaotically distributed fragments of metacherts and graphite schists are common. Fracture planes are widely dispersed only three distinguished sets are analogous to the fractures in the excavations of object no. 1: $j_{1}$ (NE-SW-oriented), $j_{2}$ (WNW-ESE-oriented) and $\mathrm{j}_{3}$ (NNW-SSE-oriented; cf. Fig. 5F).
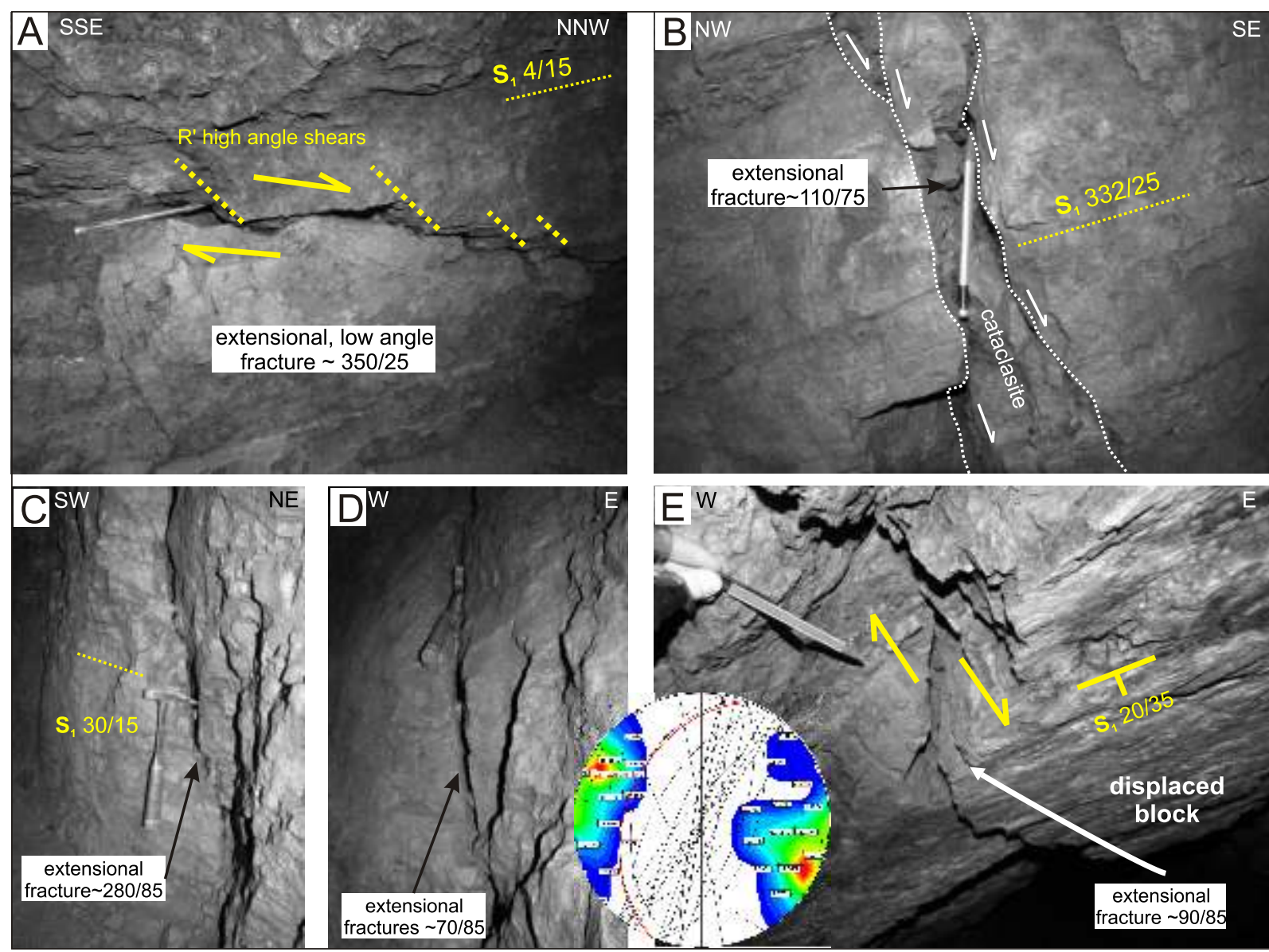

Fig. 7. Dilatational extensional cracks and fractures observed within excavations of object no. 1

A - low-angle extensional fracture developed along foliation plane $s_{1}$ in the first part of the adit (section A) in metacherts; B high-angle extensional fracture filled with crushed rock material (cataclasite) developed along a $\mathrm{j}_{2}$ fracture in section $\mathrm{B}$; bounding blocks display traces of displacements (marked by arrows); C, D - high-angle extensional cracks exposed in sections B and G, respectively; $\mathbf{E}$ - high-angle extensional crack affecting the top of the exploitation chamber; measurements of fracture planes observed in all excavations are shown on pole point, great circle and contour diagrams with marked contour intervals marked

Fig. 6. Structural features of metacherts and sericite schists observed within excavations of object no. 1

A - homoclinally NW-dipping foliation planes $\left(\mathrm{s}_{1}\right)$ of metacherts measured in section $\mathrm{B}$; measurements are shown on pole point and great circle diagrams; B - wide-radius, non-cylindrical fold with axis inclined gently to NE (section E); normal fault related to folding processes is also observed; C - small-scale kink fold observed in sericite schists in section C; D - regularly fractured metacherts exposed in section E; main joint sets ( $j_{1}$ and $j_{2}$, green lines) and foliation planes ( $s_{1}$, black lines) are marked on photograph and on great circle diagram; $\mathbf{E}-\mathrm{NE}$-dipping normal dip-slip fault that cuts foliation surfaces exposed in section C; cataclasites marked on photograph are related to fault zone; $\mathbf{F}-$ fault breccia associated with normal dip-slip, NE-dipping fault exposed in section C; measurements of fault planes are shown on pole point, great circle and contour diagrams with contour intervals marked; G - normal fault surface with visible slickensides, fault steps and R' shears which indicate sense of movement on the fault surface (marked by arrows); $\mathbf{H}$ - elongated, strongly cataclased clast of sericite schist between metacherts exposed in section $\mathrm{C}$ 
EXPOSURES ON THE SLOPES OF THE KACZAWA VALLEY

On the steeply inclined slopes of Kaczawa Valley (loc. 6 and 7) there occur distinct rock walls and cliffs with heights up to $4.5 \mathrm{~m}$, built of metacherts and siliceous schists (Fig. 8A). The metacherts and siliceous schists dip at low angles $\left(3-30^{\circ}\right)$ to the S and SSW, subordinately to the SSE (Fig. 8A, B). In these rocks exposed in situ occur joint sets analogous to those in the excavation of object no. 1. The two main joint sets have orientations at NE-SW $\left(j_{1}\right)$ and WNW-ESE $\left(j_{2}\right)$ and dips from 70 to $90^{\circ}$; two oblique sets have orientations at NW-SE $\left(\mathrm{j}_{3}\right)$ and WSW-ENE $\left(\mathrm{j}_{4}\right)$ and dips from 70 to $85^{\circ}$ (Fig. 8C).

Extensional fractures and dip-slip normal faults with strikes at NE-SW and dips of up to $60^{\circ}$ to the NE, formed along the planes of the joint set $j_{2}$, have been observed in the exposures. Foliation planes and fractures within these rock blocks are characterized by a reverse rotation of about $10^{\circ}$ (foliation $s_{1}$ with a dip of $\sim 35^{\circ}$ to the SW; cf. Fig. 8D) in relation to the metacherts and siliceous siltstones occurring in the landslide bedrock, which are inclined here at $\sim 5-10^{\circ}$ to the SW. In the metacherts exposed in the upper part of the valley slopes there occur also normal dip-slip faults with a listric geometry and $\mathrm{N}-\mathrm{S}$ strike, related to the gravitational displacement of rigid rock blocks (Fig. 8E).

\section{INTERPRETATION AND DISCUSSION}

Mass movements on Wielisławka Mt. have affected almost the entire slope built of igneous rocks and metamorphic rocks of their cover (cf. Fig. 2). During the mass movements the rhyolitic part of massif became sub-divided into blocks, along vertical or steeply dipping joint fractures $j_{1}, j_{2}$ and $j_{3}$; successively the
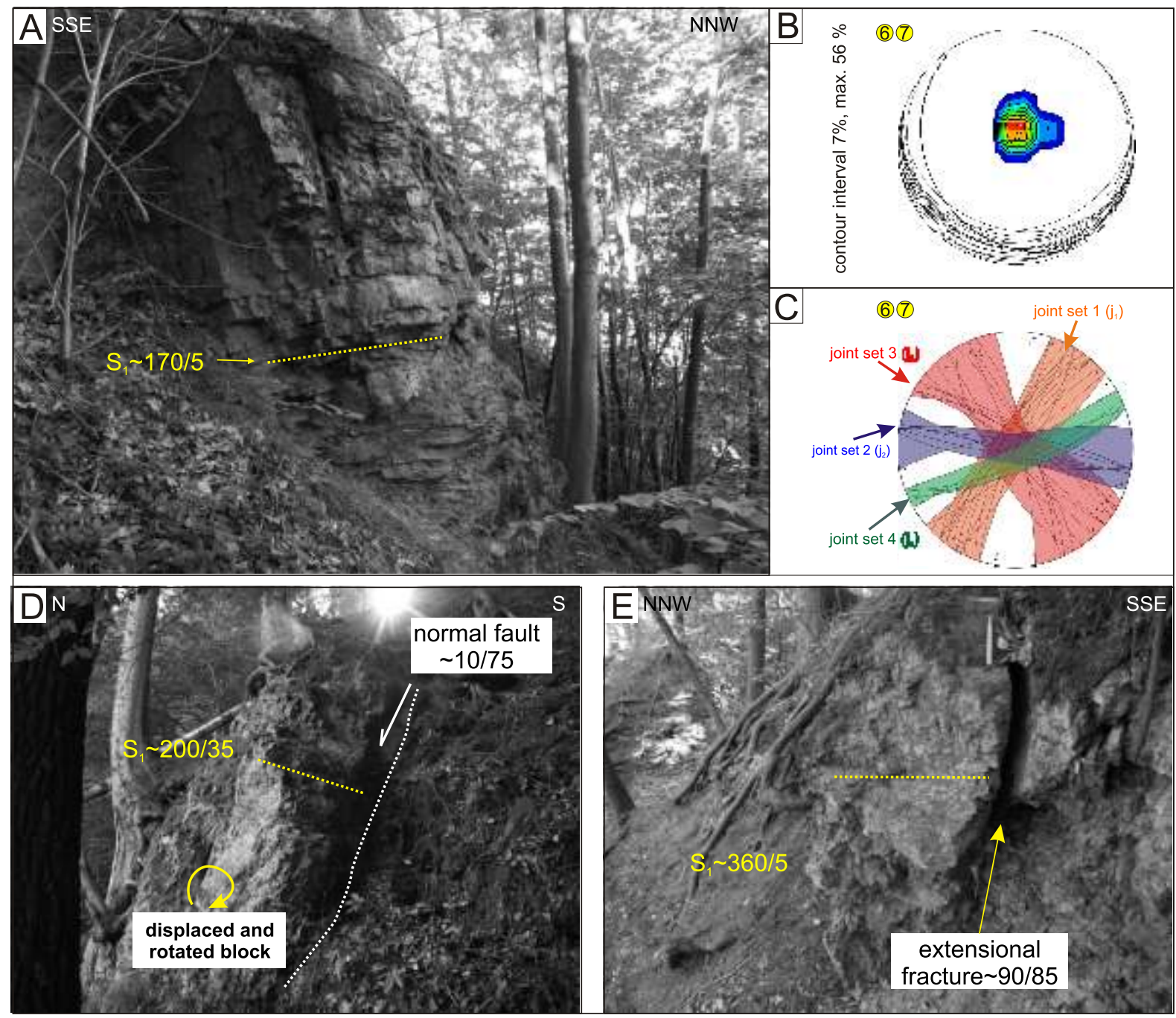

Fig. 8. Structural features of metacherts and sericite schists observed within cliffs on the steeply inclined slopes of the Kaczawa River valley

A - homoclinally S-dipping foliation planes $\left(s_{1}\right)$ of metacherts measured within cliff. 1 ; $\mathbf{B}$ - foliation planes measured within cliffs on the valley slopes shown on contour, pole point and great circle diagrams; $\mathbf{C}$ - intepretation of joint sets distinguished within cliffs on the valley slopes shown on pole point and great circle diagrams; $\mathbf{D}$ - reversely rotated rock block exposed on the slopes of the Kaczawa River valley; note rotation of foliation planes $\mathrm{s}_{1}$ in relation to those exposed within cliffs which are in situ position (cf. sites no. 6, 7); $\mathbf{E}$ - normal dip-slip faults and extensional fracture developed along $\mathrm{j}_{2}$ joint exposed in the upper part of the Kaczawa River valley 

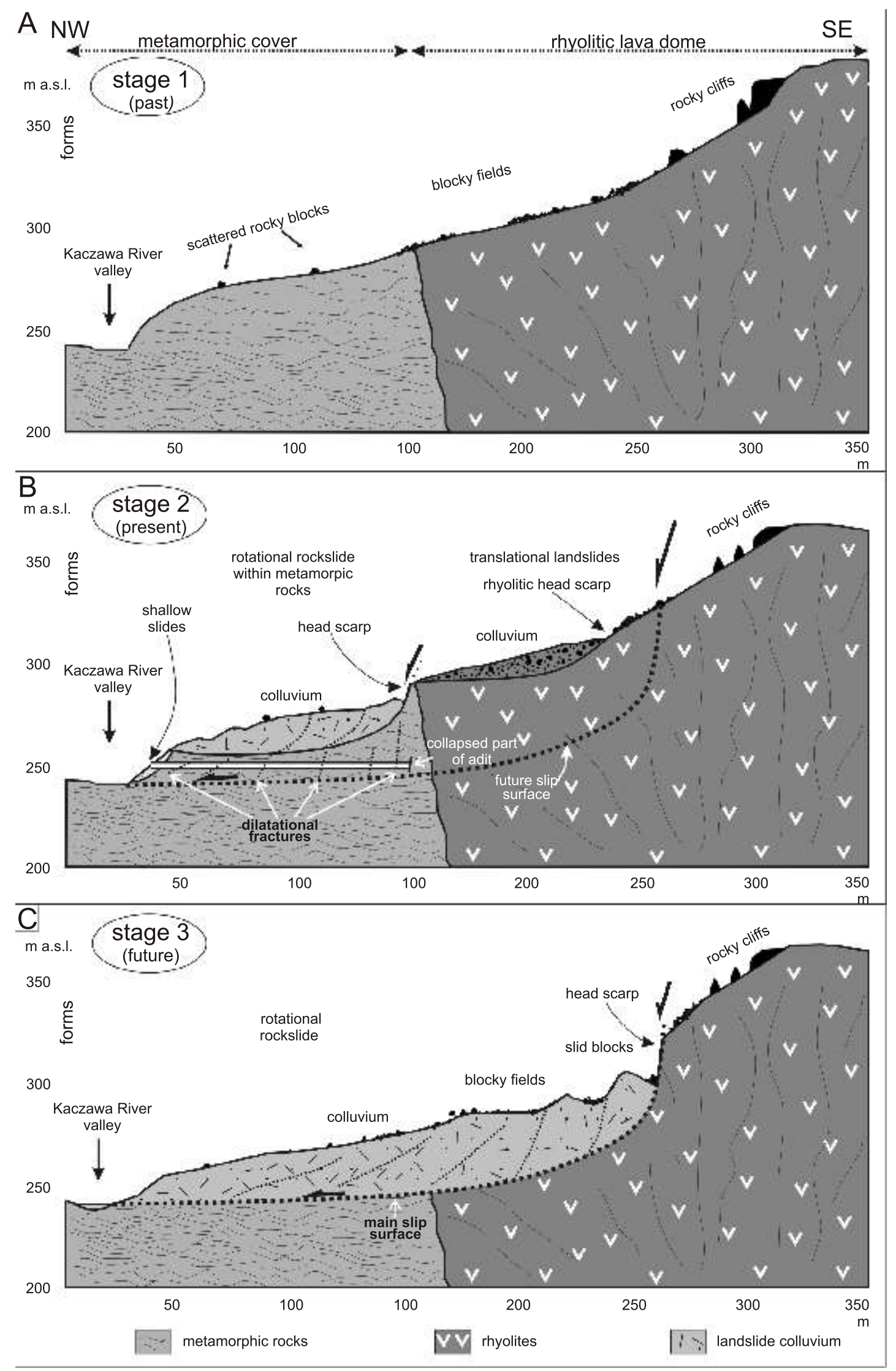

Fig. 9. Evolutionary model of mass movements affecting the northern slopes of Wielisławka Mt.

Present-day morphology obtained from LiDAR DEM is shown in Figure $9 \mathrm{~B}$; morphology from Figure $9 \mathrm{~A}$ and C is postulated for past and future stages of landslide development; for explanations see the text 
blocks were gravitationally displaced along fractures $j_{5}$ corresponding to the planes of magmatic foliation. In the initial phase of the process (Fig. 9; stage 1), extensional cracks developing along the steep joint fractures in the rhyolites became wider. At present this process is observed within cliffs, which are subject to disintegration and gradual decomposition along the discontinuity planes described.

Partial fragmentation of the blocks caused subsequent rapid displacement and accumulation of rock masses within colluvia at the base of the head scarps. Steep rhyolitic scarps, colluvial bulges and block tongues, which developed in the upper, southwestern part of the landslide analysed, and the lack of rotated rock blocks, point to translational mass movements (Fig. 9; stage 2). There is no evidence for a deep-seated slip surface in the upper part of the western landslide, and for rotation of rhyolitic slid blocks along a horizontal axis. After the translational phase of landsliding a gradual overloading of the slope by rhyolitic blocks, often of large sizes, led to secondary, shallow slides (Fig. 9; stage 2, upper section of slope). A similar displacement mechanism, although at a much smaller scale, took place in the central and northeastern part of the landslide, where rock blocks, colluvial bulges and block tongues occur at the base of low (up to $5 \mathrm{~m}$ ), but steep rhyolitic escarpments, in some cases covered by rocky talus. In the northeastern part of the landslide, the forms developed below the rocky scarps are blurred by excavations of short adits and the adjacent slagheaps. Although mass movements occurred also in the lower part of the slope built of metamorphic rocks, mostly the rhyolitic material (large blocks and rocky talus) was gravitationally displaced in the upper section of the slope. Most probably, earthor mudflows may finally have occurred, as indicated by parts of the slope with a hilly relief and low-relief landslide tongues composed of poorly sorted rock material mixed with fine-grained slope deposits.

Different displacements took place in the central part of the landslide analysed (Fig. 9; stage 2, middle and lower sections of slope), where steep, arch-shaped head scarps, up to $12 \mathrm{~m}$ in height, are associated with gravitationally displaced and rotated slid blocks built of metamorphic rocks (cf. Fig. 2). A few surface measurements of foliation planes $\mathrm{s}_{1}$ in sericite schists (see: Fig. 5) may indicate reverse rotation of foliation planes to the SW. Detachment of rock masses within the metamorphic rocks probably took place along fracture planes of joint set $j_{1}$ and subordinately $\mathrm{j}_{4}$, with an orientation of NE-SW and WSW-ENE, respectively. Main displacements on the main slip surface in the lower part of the landslide took place along $s_{1}$ foliation planes developed in sericite schists and cherts, which dip homoclinally to the NW. Primary sedimentary structures are preserved within these metamorphic rocks (Baranowski, 1975), and the presently observed fracture and foliation planes largely correspond to the primary sedimentary planes and joint fractures in the sedimentary rocks (protolith). Moreover, in their origin and rheology, metamorphic rocks in the study area correspond to flysch rocks, as has been noted already in the 1970s (Baranowski, 1975). These rocks include metamorphosed and lithologically diverse types of densely fractured, easily deformed and plastic fine-grained rocks (phyllites), as well as massive metacherts and metasiltsones. The variability of rheological properties within these rocks was one of the factors supporting the development of mass wasting in the study area.

Local zones of axial cleavage that developed in the hinges of the wide-radius folds have almost no influence on the development of the slip surface. Regardless of the processes described and discussed above, shallow mass movements affecting metachert exposures take place presently on the steep slopes of the Kaczawa Valley in the distal parts of the western landslide (Fig. 9B, lower section of slope). This process is seen as rotated metachert blocks and extensional cracks observed in exposures on the valley slopes (cf. Fig. 8).

Important premises on the development of mass movements in the central part of the Wielisławka Mt. slopes come from structural analyses made in the network of underground excavations of object no. 1, dug in the lower and middle parts of the landslide area. Although the underground excavations were probably made below the main slip surface of the landslide studied (cf. Fig. 9B), evidence of opening of fractures indicating gradual relaxation of the rock massif, leading to the development of a subsequent, deeper slip surface in the rock mass, have been observed. The structures described resulted from dilation (Reynolds, 1885; Neuendorf et al., 2005). This geomechanical process led to the opening and widening of fractures in the rock massif, and thus to the development of a landslide slip surface by shearing of the rock masses (cf. Margielewski and Urban, 2017). Development of a subsequent slide plane is indicated by numerous low-angle extensional cracks which formed along foliation planes $s_{1}$ in the metacherts (Fig. $7 A)$. The cracks developed in the metamorphic rocks due to propagation of shearing strains along existing structural planes (in this case, foliation). Simultaneously, vertical or almost vertical extensional cracks developed above these planes, resulting from opening and widening of pre-existing joint fractures of the $\mathrm{j}_{1}$ and $\mathrm{j}_{2}$ sets. Their opposing orientations (cf. Fig. 5) suggests the gradual subdivision of the rock massif into horst-and-graben blocks, this being the initial stage of the development of a deep landslide (Fig. 9B, C; stage 2 and 3). Numerous cataclastic zones and NW-SE-oriented faults observed in the terminal part of object no. 1 (Fig. 5, section C) directly correspond to the orientation of the landslide head scarp, which indicates partial development of the slide planes along such oriented discontinuity surfaces.

The depth at which the slide surface occurs in the central part of the slope built of metamorphic rocks is an unresolved issue. The height of the head scarp that originated within the sericite schists (297-284 m a.s.I.), and the lack of large-scale displacements in the initial parts of object no. 1, exclude the possibility that a deeply-seated slide surface reached the mining excavations at an elevation of $\sim 249 \mathrm{~m}$ a.s.l. At the same time, the presence of extensional cracks and fractures confirms the development of a deeper slide surface below the adits and excavations (cf. Fig. 9B; dotted line). Further evolution of mass movements in the study area may be seen also as tightening of the terminal parts of object no. 1 along faults, as well as numerous collapses in the mining area and its surroundings. Although extensional cracks and fractures, linked herein with gravitational processes, may not necessarily take place due to mass movements, e.g. due to natural collapse and tightening of old mining excavations (Chudek and Du y, 2005), their orientation perpendicular to most excavations of object no. 1 undisputedly indicates a gravitational origin. Similarly, low-angle dilatational fissures, oriented parallel to the landslide head scarps and slid blocks, point to the next phase of gravitational displacement within the massif (Fig. 9C; stage 3).

Another issue is the age of the landslide processes described both in the study area and across the whole area of the Sudetes Mountains. Although different stages of development and stepwise sequences of slope instability were suggested for many individual landslide forms in the Sudetes (cf. Synowiec, 2003; Migoń et al., 2016b; Kowalski, 2017a), the absolute age of the individual landslides remains unclear and as yet unconstrained (cf. Migoń et al., 2016b). Synowiec (2005) dated two samples of sediments derived from peat bogs within the Rogowiec landslide complex in the Kamienne Mountains, Central 
Sudetes (cf. Kasprzak et al., 2016) and obtained mid- to late Holocene dates. Hence many forms occurred within this mountain range were generally considered to be a mid-Holocene or Late Pleistocene in age (Migoń et al., 2016b). On the other hand, the area of the Kamienne Mountains has never been glaciated and it was located in the periglacial zone during the Quaternary glaciations (Migoń et al., 2017). Thus, landslides occurring within this mountain range cannot be directly related to deglaciation process.

By contrast, it is widely accepted that the Kaczawskie Fotthills area, Western Sudetes, were reached by the Scandinavian ice sheet at least twice (Woldstedt, 1932; Lindner, 1939; Kowalski et al., 2018). Hence, slope debuttressing process after deglaciation can be considered as one of the triggering factors that caused the landslide development on Wielisławka Mt. However, though this possibility, as well as the role of neotectonics on landslide development, can be taken into consideration regarding the nature and age of mass movements in the Sudetes area, it remains a matter of conjecture.

\section{CONCLUSIONS}

The multi-method approach applied here in landslide investigations has allowed elucidation of the mechanisms and development of mass movements that have occurred on, and that may encompass in the future, the northern slopes of Wielisławka Mt. Based on the results of structural analysis coupled with terrestrial laser scanning, geomorphological mapping and geomorphometric analysis of LiDAR DEMs, the course of landslide processes in the study area was reconstructed. The results obtained indicate that the intensity, development and potential future evolution of the slope failures on Wielisławka Mt. are influenced by existing discontinuity surfaces within the rock massif, such as opened fractures and faults in igneous and metamorphic rocks. Therefore, the concept of structural controls on the landslide forms in the study area seems well grounded based on the results obtained.

The morphology and further development of landslides on the northern slopes of. Wielisławka Mt. are directly related to fluvial erosion and the formation of the deeply incised Kaczawa River gorge. Lithological and structural anisotropy of the massif played an important role in slope failure development. Significant is the lack of large-scale displacement of rock masses on the western slopes of the hill, built exclusively of massive and columnar rhyolites, despite the very high values of slope inclination $\left(36-42^{\circ}\right)$. This indicates the large role of lithology and pre-existing discontinuities in the initiation of landslide processes.

Development of the landslides on Wielisławka Hill was probable preceded by the formation of vertical extensional cracks accompanying the lateral spreading which caused fragmentation of the massif into individual rock blocks and their forward or backward toppling. Displacement of large rhyolitic blocks triggered the formation of shallow landslides. Discontinuity surfaces along which such processes took place are visible in the landslide head scarps. Translational slips could take place only on parts of slopes built of rhyolite and these occur in the SW part of the landslide studied. Due to the fact that the fracture planes are mostly steep $\left(70-90^{\circ}\right)$, and the discontinuities corresponding to magmatic foliation are not penetrative at the scale of the entire massif, the lower part of the landslide slip surface likely developed along one or more shear surfaces localized within the metamorphic rocks. It is most probably a combination of the foliation planes with shear planes obliquely cutting $s_{1}$ foliation surfaces in the metamorphic rocks. Surprisingly, the deepest foundations of the landslide slip surfaces occur in the middle slope section of Wielisławka Mt. Measurements made in the southern part of the underground excavations of object no. 1 indicate the direct impact of normal faults on the formation of the upper part of the slip surface. These faults significantly influenced the fragmentation of the massif.

Our observations suggest that progressive gravitational slope deformation which originated in shallow translational landslides may evolve into rapid slides due to acceleration of shearing and large-scale rock mass displacements at the base of the slope. The geometry and shape of the upper and the lower parts of the sliding surface are closely linked with pre-existing structural discontinuities within the massif. Due to the location of the mining excavations below the presently active landslide, the adits on Wielisławka Hill are unique study objects allowing for the observation and reconstruction of landslide processes.

Acknowledgments. Authors would like to thank O. Krejčí from Czech Geological Survey and an anonymous reviewer for their critical reading and valuable comments on the first version of the manuscript. M. Krapiec is acknowledged for his support and help during editorial processes. We are also grateful to $\mathrm{A}$. ylińska for the linguistic improvement of the manuscript as well as K. Maciejak and A. Kozłowski for their assistance and help during fieldwork in the old adits. The authors would also like to thank TPI Ltd. Company for assisting in measurements of underground excavations. This research was partially funded by Research Project no. 0420/2678/18 of the Institute of Geological Sciences, University of Wrocław (for A. Kowalski) and no. 0402/0041/18 and 0402/0039/18 of the Wroctaw University of Science and Technology (for D. Kasza and J. Wajs). LiDAR data have been used for this study on the basis of the academic licence No. DIO.DFT.DSI.7211.1619.2015 PL N issued for the University of Wrocław by the Head Office of Geodesy and Cartography in Poland.

\section{REFERENCES}

Agliardi, F., Crosta, G.B., Meloni, F., Valle, C., Rivolta, C., 2013. Structurally-controlled instability, damage and slope failure in a porphyry rock mass. Tectonophysics, 605: 34-47.

Avelar, A.S., Coelho Netto, A.L., Lacerda, W.A., Becker, L.B. Mendonça, M.B., 2011. Mechanisms of the recent catastrophic landslides in the mountainous range of Rio de Janeiro, Brazil. Proceedings of the Second World Landslide Forum - 3-7 October 2011, Rome.

Awdankiewicz, M., Szczepara, N., 2009. Structure, textures, petrography and mineral chemistry of the Wielisławka rhyolites
(Permian), the North-Sudetic Basin. Mineralogia - Special Papers, 34: 10.

Bahat, D., 1991. Tectonofractography. Springer-Verlag, Berlin, Heidelberg.

Baranowski, Z., 1975. Metamorphosed flysch deposits in the northern Kaczawa Mts. (Rzeszówek-Jakuszowa Unit). Geologia Sudetica, 10: 119-145.

Baranowski, Z., Haydukiewicz, A., Kryza, R., Lorenc, S., Muszyński, A., Solecki, A., Urbanek Z., 1990. Outline of the geology of the Góry Kaczawskie (Sudetes, Poland). Neues Jahrbuch für Geologie und Paläontologie Abhandlungen, 179: 223-257. 
Baroň, I., Kernstocková, M., Faridi, M., Bubík, M., Milovskýd, R., Melichar, R., Sabouri, J., Babůrek, J., 2013. Paleostress analysis of a gigantic gravitational mass movement in active tectonic setting: the Qoshadagh slope failure, Ahar, NW Iran. Tectonophysics, 605: 70-87.

Berns, K., von Puttkamer, E., 2009. Simultaneous localization and mapping (SLAM). In: Autonomous Land Vehicles. Vieweg + Teubner, doi: doi.org/10.1007/978-3-8348-9334-5 6

Birk, A., Pfingsthorn, M., 2016. Simultaneous Localization and Mapping (SLAM). Wiley Encyclopedia of Electrical and Electronics Engineering, doi: 10.1002/047134608X.W8322

Carlini, M., Chelli, A., Vescovi, P., Artoni, A., Clemenzi, L., Tellini, C., Torelli, L., 2016. Tectonic control on the development and distribution of large landslides in the Northern Apennines (Italy). Geomorphology, 253: 425-437.

Cedro, B., Mianowicz, K., Zawadzki, D., 2009. Ocena walorów geoturystycznych stanowisk pochodzenia wulkanicznego Gór i Pogórza Kaczawskiego (in Polish). In: Problemy turystyki i rekreacji (ed. M. Dudkowski). Oficyna In Plus, Szczecin, 2: 25-35.

Chudek, M., Du y, S., 2005. Geotechniczne problemy utrzymania wyrobisk korytarzowych w zło onych warunkach geologiczno-górniczych (in Polish). Górnictwo i Geoin ynieria, 29: 157-164

Cymerman, Z., 2002. Structural and kinematic analysis and the Variscan tectonic evolution of the Kaczawa Complex (the Sudetes) (in Polish with English summary). Prace Państwowego Instytutu Geologicznego, 175: 1-143

Daneshvar, M.R.M., Bagherzadeh, A., 2011. Landslide hazard zonation assessment using GIS analysis at Golmakan Watershed, northeast of Iran. Frontiers of Earth Science, 5: 70-81.

Dewez, T.J.B., Plat, E., Degas, M., Richard, T., Pannet, P., Thuon, Y., Meire, B., Watelet, J.-M., Laurent Cauvin, L., Lucas, J., Dian, G., 2016. Handheld Mobile Laser Scanners Zeb-1 and Zeb-Revo to map an underground quarry and its above-ground surroundings. Virtual Geoscience Conference, 22-23 Sept. 2016, Bergen, Norway.

Dikau, R., Brunsden, D., Schrott, L., Ibsen, M.L. eds., 1996 Landslide Recognition. Identification, Movement and Causes. J. Willey and Sons.

Duszyński, F., Jancewicz, K., Kasprzak, M., Migoń, P., 2017. The role of landslides in downslope transport of caprock-derived boulders in sedimentary tablelands, Stołowe Mts, SW Poland. Geomorphology, 295: 84-101.

Eyre, M., Wetherelt, A., Coggan, J., 2016. Evaluation of automated underground mapping solutions for mining and civil engineering applications. Journal of Applied Remote Sensing, 10: 046011.

Fleming, R.W., Johnson, A.M., 1989. Structures associated with strike-slip faults that bound landslide elements. Engineering Geology, 27: 39-114.

Fort, M, Cossart, E., Deline, P., Dzikowski, M., Nicoud, G., Ravanel, L., Schoeneich, P., Wassmer, P., 2009. Geomorphic impacts of large and rapid mass movements: a review. Géomorphologie: Relief, Processus, Environnement, 15: 47-64.

Frąckiewicz, W., 1958. Szczegółowa Mapa Geologiczna Sudetów 1:25 000, arkusz Świerzawa (in Polish). Wyd. Geol., Warszawa.

Herrera, G., Mateos, R.M., García-Davalillo, J.C., Grandjean, G., Poyiadji, E., Maftei, R., Filipciuc, T-C., Auflič, M.J., Jež, J., Podolszki, L., Trigila, A., ladanza, C., Raetzo, H., Kociu, A., Przyłucka, M., Kułak, M., Sheehy, M., Pellicer, X.M., McKeown, C., Ryan, G., Kopačková, V., Frei, M., Kuhn, D., Hermanns, R.L., Koulermou, N., Smith, C.A., Engdahl, M., Buxó, P., Gonzalez, M., Dashwood, C., Reeves, H., Cigna, F., Liščák, P., Pauditš, P., Mikulènas, V., Demir, V., Raha, M., Quental, L., Sandić, C., Fusi, B., Jensen, O.A., 2018. Landslide databases in the Geological Surveys of Europe. Landslides, 15: 359-379.

Humair, F., Pedrazzini, A., Epard, J-L., Froese, C.R., Jaboyedoff, M., 2013. Structural characterization of Turtle Mountain anticline (Alberta, Canada) and impact on rock slope failure. Tectonophysics, 605: 133-148.

Hungr, O., Leroueil, S., Picarelli, L., 2014. The Varnes classification of landslide types, an update. Landslides, 11: 167-194.

Jaboyedoff, M., Oppikofer, T., Derron, M.H., Blikra, L.H., Böhme M., Saintot, A., 2011. Complex landslide behaviour and structural control: a three-dimensional conceptual model of Cknes rockslide, Norway. Geological Society London Special Publications, 351: 147-161.

Jahn, A., 1960. Czwartorzęd Sudetów (in Polish). In: Regionalna geologia Polski, t. III, Sudety (ed. H. Teisseyre): 358-418. PTGeol. Kraków.

Jancewicz, K., Traczyk, A., 2017. Little known mass movement forms in the Węglówka valley, Bardzkie Mts (Sudetes) (in Polish with English summary). Przyroda Sudetów, 20: 289-314.

Jerzmański, J., 1956. Porfir wzgórza Wielisławka w Górach Kaczawskich (in Polish). Przegląd Geologiczny, 4: 174-175.

Kasprzak, M., Duszyński, F., Jancewicz, K., Michniewicz, A. Ró ycka, M., Migoń, P., 2016. The Rogowiec Landslide Complex (Central Sudetes, SW Poland) - a case of collapsed mountain. Geological Quarterly, 60 (3): 695-713.

Kojima, S., Nagata, H., Yamashiroya, S., Iwamoto, N., Ohtani, T., 2015. Large deep-seated landslides controlled by geologic structures: prehistoric and modern examples in a Jurassic subduction - accretion complex on the Kii Peninsula, central Japan. Engineering Geology, 186: 44-56.

Kondracki, J., 2002. Geografia regionalna Polski (in Polish). PWN Warszawa.

Kong, Z., Lu, Q., 2017. A brief review of simultaneous localization and mapping. IECON 2017 - 43rd Annual Conference of the IEEE Industrial Electronics Society, doi: 10.1109/IECON.2017.8216955

Kowalski, A., 2017a. Impact of mass movements on geological interpretation - an example of the Drogosz hill landslide within the Zawory Range (Central Sudetes) (in Polish with English summary). Przegląd Geologiczny, 65: 96-104.

Kowalski, A., 2017b. Distribution and origin of landslide forms in the Bóbr river valley near Wleń (Western Sudetes) (in Polish with English summary). Przeglad Geologiczny, 65: 629-641.

Kowalski, A., Wojewoda, J., 2017. Newly recognised landslide forms in the Kaczawa river valley (Kaczawskie Foothills, Western Sudetes) (in Polish with English summary). Landform Analysis, 34: 15-27.

Kowalski, A., Makoś, M., Pitura, M., 2018. New insights into the glacial history of southwestern Poland based on large-scale glaciotectonic deformations - a case study from the Czaple II Gravel Pit (Western Sudetes). Annales Societatis Geologorum Poloniae, 88: 341-359.

Kowalski, A., Makoś, M., 2019. Geologiczne uwarunkowania rozwoju osuwisk w Sudetach (in Polish). 2. Ogólnopolska Konferencja Osuwiskowa O!SUWISKO, 14.05.2019-17.05.2019, Szczawnica: Materiały Konferencyjne. Państwowy Instytut Geologiczny, Warszawa.

Kozłowski, S., Parachoniak, W., 1967. Wulkanizm permski w depresji północnosudeckiej (in Polish). Prace Muzeum Ziemi 11, Warszawa: 191-221.

Kryza, R., Muszyński, A., 1992. Pre-Variscan volcanic-sedimentary succession of the central southern Góry Kaczawskie, SW Poland: outline geology. Annales Societatis Geologorum Poloniae, 62: 117-140.

Ksia kiewicz, M., 1972. Karpaty. In: Budowa geologiczna Polski, t IV, Tektonika (in Polish). Polskie Towarzystwo Geologiczne, Kraków.

Lindner, H., 1939. Die Gnadenfelder saaleelszeltllche Endstaffel und die Bewegung des Saale-Eises in Oberschlesien. Jahresberichte der Geologischen Vereinigung Oberschlesiens, 1939: 1-19.

Maciejak, K., Kowalski, A., Maciejak, M., 2017. Goldmines of the Wielisławka hill (Kaczawa Upland) (in Polish with English summary). Hereditas Minariorum, 4: 45-63.

Mancini, F., Ceppi, C., Ritrovato, G., 2010. GIS and statistical analysis for landslide susceptibility mapping in the Daunia area, Italy. Natural Hazards and Earth System Sciences, 10: 1851-1864.

Margielewski, W., 2006. Structural control and types of movements of rock mass in anisotropic rocks: case studies in the Polish Flysch Carpathians. Geomorphology, 77: 47-68.

Margielewski, W., Urban, J., 2017. Gravitationally induced non-karst caves: tectonic and morphological constrains, classification, and dating; Polish Flysch Carpathians case study. Geomorphology, 296: 160-181.

Migoń, P., Jancewicz, K., Kasprzak, M., 2014. The extent of landslide-affected areas in the Kamienne Mountains (Middle Sude- 
tes) - a comparison of geological maps and a LiDAR based digital elevation model (in Polish with English summary). Przegląd Geologiczny, 62: 463-471

Migoń, P., Ró ycka, M., Jancewicz, K., 2016a. The landslide complex on Mt. Toczek (Bystrzyckie Mts) in the light of geomorphometric analysis (in Polish with English summary). Przyroda Sudetów, 19: 167-188.

Migoń, P., Jancewicz, K., Ró ycka, M., Duszyński, F., Kasprzak, M., 2016b. Large-scale slope remodelling by landslides - geomorphic diversity and geological controls, Kamienne Mts., Central Europe. Geomorphology, 289: 134-151.

Migoń, P., Duszyński, F., Kasprzak, M., Ró ycka, M., 2017. Evolv ing slope instability zone at. Mt. Turzyna (Sudetes, SW Poland) - an example of incipient deep-seated gravitational slope deformation. Zeitschrift für Geomorphologie, 61/2: 135-148.

Mikulski, S.Z., 2007. The late Variscan gold mineralization in the Kaczawa Mountains, Western Sudetes. Polish Geological Institute Special Papers, 22: 1-162.

Mikulski, S.Z., Williams, I.S., 2014. Zircon U-Pb dating of igneous rocks in the Radzimowice and Wielisław Złotoryjski auriferous polymetallic deposits, Sudetes, SW Poland. Annales Societatis Geologorum Poloniae, 84: 213-233.

Milewicz, J., Kozdrój, W., 1995. Szczegółowa Mapa Geologiczna Sudetów 1:25 000 arkusz Proboszczów (in Polish). Państwowy Instytut Geologiczny, Warszawa.

Neuendorf, K.K.E., Mehl Jr., J.P., Jackson, J.A., 2005. Glossary of Geology. 5th Ed. American Geological Institute, Alexandria, Virginia.

Nocerino, E., Menna, F., Remondino, F., Toschi, I., Rodríguez-Gonzálvez, P., 2017. Investigation of Indoor and Outdoor Performance of Two Portable Mobile Mapping Systems. Proc. SPIE 10332, Videometrics, Range Imaging, and Applications XIV, 103320I, DOI: doi.org/10.1117/12.2270761

Petit, J.P., 1987. Criteria for the sense of movement on fault surfaces in brittle rocks. Journal of Structural Geology, 9: 597-608.

Petrakov, D.A., Chernomorets, S.S., Evans, S.G., Tutubalina, O.V., 2008. Catastrophic glacial multi-phase mass movements: a special type of glacial hazard. Advances in Geosciences, 14 211-218.

Poprawa, D., Rączkowski, W., 2003. Carpathian landslides (southern Poland) (in Polish with English summary). Przegląd Geologiczny, 51: 685-692.

Report, 2011. Raport dostawy, ISOK - Informatyczny System Osłony Kraju przed nadzwyczajnymi zagro eniami (in Polish). Część nr 3, Etap nr 03, 2011-09-12.

Reynolds, 0., 1885. On the dilatancy of media composed of rigid particles in contact, with rocks: case studies in the Polish Flysch Carpathians. Geomorphology, 77: 47-68.

Romagós, D.R., Ridao, P., Neira, J., 2010. Simultaneous Localization and Mapping. In: Underwater SLAM for Structured Environments Using an Imaging Sonar, Springer Berlin Heidelberg.

Ró ycka, M., Michniewicz, A., Migoń, P., Kasprzak, M., 2015. Identification and morphometric properties of landslides in the Bystrzyckie Mountains (Sudetes, SW Poland) based on data derived from airborne LiDAR. Geomorphometry for Geosciences, 1: 247-250.

Sammartano, G., Spanb, A., 2018. Point Clouds by SLAM-based Mobile Mapping Systems: Accuracy and Geometric Content Validation in Multisenson Survey and Stand-alone Acquisition. Applied Geomatics, Springer Berlin Heidelberg doi: doi.org/10.1007/s12518-018-0221-7

Sassa, K., Tiwari, B., Liu, K.-F., McSaveney, M., Strom, A., Setiawan, H. eds., 2018. Landslide Dynamics: ISDR-ICL Landslide Interactive Teaching Tools, Volume 2: Testing, Risk Management and Country Practices, Springer International Publishing.

Scheidegger, A.E., 1998. Tectonic predesign of mass movements, with examples from the Chinese Himalaya. Geomorphology, 26: 37-46.

Schleier, M., Hermanns, R.L., Krieger, I., Oppikofer, T., Eiken, T., Rrnning, J.S., Rohn, J., 2016. Gravitational reactivation of a pre-existing post-Caledonian fault system: the deep-seated gravitational slope deformation at Middagstinden, western Norway. Norwegian Journal of Geology, 96: 1-23.
Schroder, J.F., 2014. Landslide Hazards, Risks, and Disasters. Academic Press.

Sikora, R., Wojciechowski, T., 2019. Landslides in the Sudetes (in Polish with English summary). Przegląd Geologiczny, 67: 360-368.

Śliwiński, W., Raczyński, P., Wojewoda, J., 2003. Sedymentacja utworów epiwaryscyjskiej pokrywy osadowej w basenie północnosudeckim (in Polish). In: Sudety Zachodnie: od wendu do czwartorzędu (eds. A. Cię kowski, J. Wojewoda and A. elaźniewicz): 1-8. WIND, Wrocław.

Solecki, A.T., 1994. Tectonics of the North Sudetic Synclinorium. Acta Universitatis Wratislaviensis nr 1618, Prace Geologiczno Mineralogiczne, 45

Stoffel, M., Huggel, C., 2012. Effects of climate change on mass movements in mountain environments. Progress in Physical Geography, 36: 421-439.

Synowiec, G., 2003. Landslides in the Kamienne Mts, Sudetes (SW Poland) (in Polish with English summary). Przegląd Geologiczny, 51: 59-65.

Synowiec, G., 2005. Formy i procesy osuwiskowe w Górach Kamiennych (in Polish). Ph.D. thesis, Instytut Geografii i Rozwoju Regionalnego, Uniwersytet Wrocławski.

Teisseyre, H., Smulikowski, K., Oberc, J., 1957. Regionalna geologia Polski t. III, Sudety, z. 1 (in Polish). Polskie Towarzystwo Geologiczne, Kraków.

Traczyk, A., 2011. Morfologia i geneza przełomowego odcinka doliny Kaczawy między Sędziszową a Nowym Kościołem na Pogórzu Kaczawskim (in Polish). Przyroda Sudetów, 14: 167-180.

Tucci, G., Visintini, D., Bonora, V., Parisi, E.I., 2018. Examination of indoor mobile mapping systems in a diversified internal/external test field. Applied Sciences, 8: 401.

Urbanek, Z., Baranowski, Z., Haydukiewicz, A., 1975. Geologiczne konsekwencje występowania dewońskich konodontów w metamorfiku północnej części Gór Kaczawskich. Geologia Sudetica, 10: 155-169.

Varnes, D.J., 1978. Slope movement types and processes. In: Landslides: Analysis and Control (eds. R.L Schuster and R.J. Krizek): 11-35. Transportation and Road Research Board, National. Academy of Science, Washington D.C.

Wajs, J., Kasza, D., Zago d on, P.P., Zago d on, K.D., 2018. 3D modeling of underground objects with the use of SLAM technology on the example of historical mine in Ciechanowice (Ołowiane Range, The Sudetes). E3S Web of Conferences, 29, 00024, https://doi.org/10.1051/e3sconf/20182900024

Werner, M., 2014. Simultaneous Localization and Mapping in Buildings. In: Indoor Location-Based Services, Springer, doi: 10.1007/978-3-319-10699-1_8

Wójcik, A., Wojciechowski, T., 2016. Landslides as one of the most important elements of geological hazards in Poland (in Polish with English summary). Przegląd Geologiczny, 64: 701-709.

Wojewoda, J., Mastalerz, K., 1989. Climate evolution, allo- and autocyclicity of sedimentation: an example from the Permo-Carboniferous continental deposits of the Sudetes, SW Poland (in Polish with English summary). Przeglad Geologiczny, 432: 173-180.

Woldstedt, P., 1932. Über Endmoränen und Oser der Saale (= Riss) Vereisung in Schlesien. Zeitschrift für Deutschen Geologischen Gesselschaften, 84: 78-84.

WP/WLI, 1990. The International Geotechnical Societes UNESCO Working Party for World Landslide Inventory. A suggested method for reporting a landslide. Bulletin International Association of Engineering Geology 41: 5-12.

WP/WLI, 1993. The International Geotechnical Societes UNESCO Working Party for World Landslide Inventory. Multilingual landslide glossary. The Canadian Geotechnical Society. BiTech Publishers Ltd, Richmond BC, Canada: 1-7.

Záruba, Q., Mencl, V., 1982. Landslides and Their Control. Elsevier Scientific Pub. Co.

Zimmermann, E., Kühn, B., 1929. Geologische Karte von Preussen 1:25 000. Blatt Schönau. Preußische Geologische Landesanstalt.

Zöller, A., 1936. Die Putzenzech am Willenberg. Ein altes Goldbergwerk bei Röversdorf unweit. 